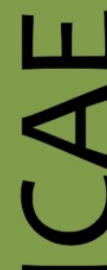

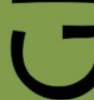

ex Instituto Archaeologico Universitatis de Rolando Eötvös nominatae

O

$\overrightarrow{0}$

山

$\leftarrow$

I

$\cup$

ه

$\leftarrow$

u

Ш

Z

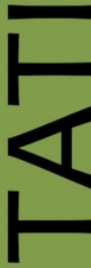

œ

ш

n

n

$\varnothing$
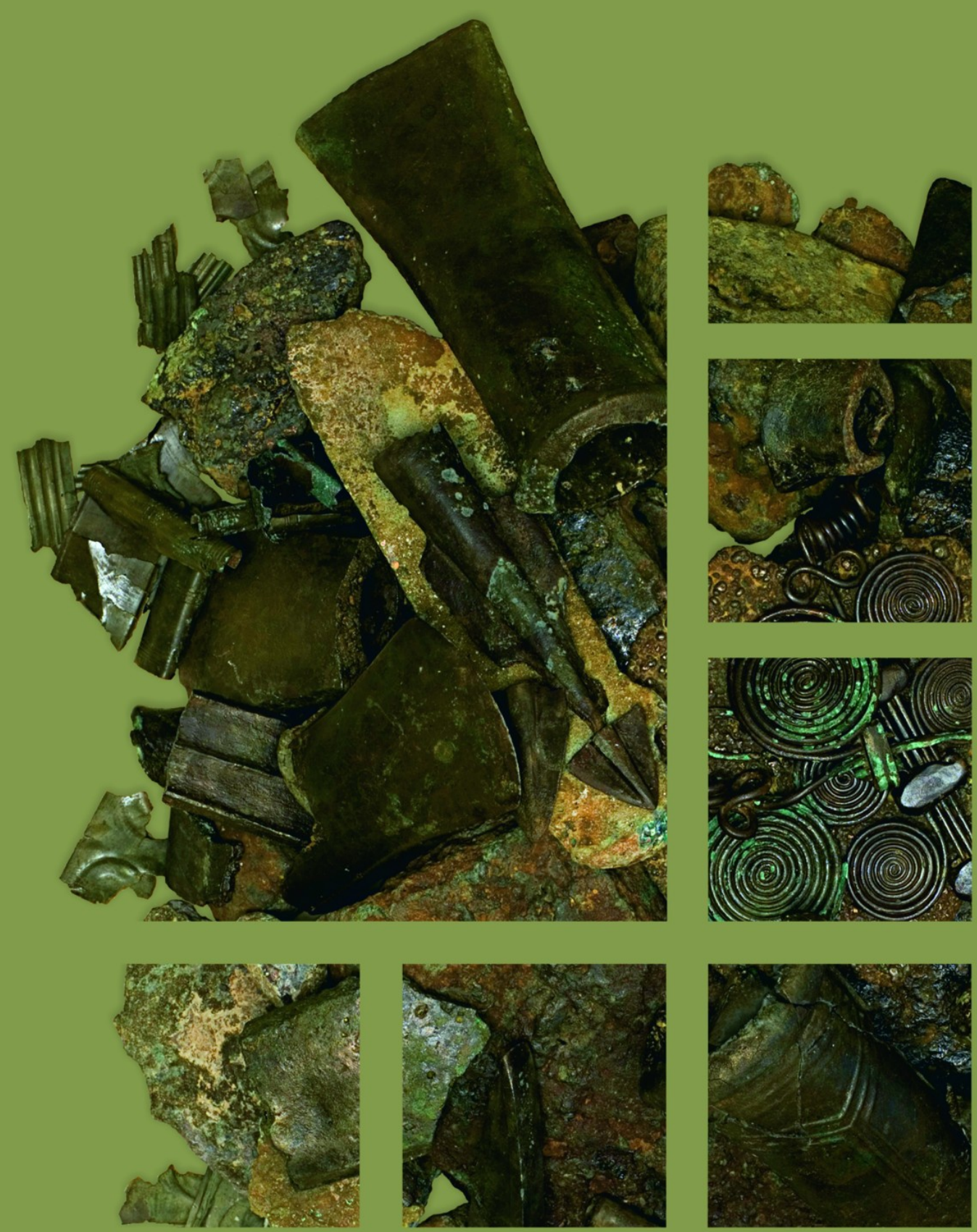


\section{Dissertationes Archaeologicae ex Instituto Archaeologico}

Universitatis de Rolando Eötvös nominatae Ser. 3. No. 2.

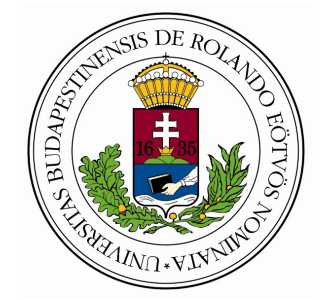

Budapest 2014 
Dissertationes Archaeologicae ex Instituto Archaeologico Universitatis de Rolando Eötvös nominatae

Ser. 3. No. 2.

Editor-in-chief:

DÁvid BARTus

Editorial board:

LÁsZló BARTOSIEWICZ

LÁSZLÓ BORHY

IsTVÁN FELD

GÁBOR KALLA

PÁL RACZKY

MiKLÓs SzABÓ

TIVADAR VIDA

Technical editors:

DÁvid BARTus

GÁBOR VÁCZI

ANDRÁs BÖDŐCS

DÁNIEL SZABÓ

Proofreading:

SZILVIA SzÖLLősI

Available online at http://dissarch.elte.hu Contact: dissarch@btk.elte.hu

$$
\begin{aligned}
& \text { PUBLIC } \\
& \text { KNOWLEDGE } \\
& \text { PROJECT }
\end{aligned}
$$

(c) Eötvös Loránd University, Institute of Archaeological Sciences

Budapest 2014 


\section{Contents}

\section{SElected PAPERS OF THE XI. Hungarian CONFERENCE on Classical Studies}

Ferenc BARNA

Venus mit Waffen. Die Darstellungen und die Rolle der Göttin in der Münzpropaganda

der Zeit der Soldatenkaiser (235-284 n. Chr.)

Dénes GABLER

A belsó vámok szerepe a rajnai és a dunai provinciák importált kerámiaspektrumában

Lajos MATHÉDESZ

Római bélyeges téglák a komáromi Duna Menti Múzeum gyújteményében

Katalin OtTOMÁNYI

Újabb római vicusok Aquincum territoriumán

Eszter SÜVEGH

Hellenistic grotesque terracotta figurines. Problems of iconographical interpretation

András SzABó

Some notes on the rings with sacred inscriptions from Pannonia

István VIDA

The coinage of Flavia Maxima Helena

\section{Articles}

Gábor TARBAY

Late Bronze Age depot from the foothills of the Pilis Mountains

Csilla SÁRó

Roman brooches from Paks-Gyapa - Rosti-puszta

András BöDőcs - Gábor KovÁcs - Krisztián ANDERKó

The impact of the roman agriculture on the territory of Savaria

Lajos JuHÁsz

Two new Roman bronzes with Suebian nodus from Brigetio

\section{FIELD REPORTS}

Zsolt MESTER - Norbert FARAGó - Attila KirÁLy

The first in situ Old Stone Age assemblage from the Rába Valley, Northwestern Hungary

Pál RACZky - Alexandra ANDERs - Norbert FARAgó - Gábor MÁRKus

Short report on the 2014 excavations at Polgár-Csőszhalom 
Preliminary Report on the first season of fieldwork in Berettyóúffalu-Szilhalom

Márton SzILÁgyi - András FüZESI - Attila VIRÁG - Mihály GASPARIK

A Palaeolithic mammoth bone deposit and a Late Copper Age Baden settlement and enclosure

Preliminary report on the rescue excavation at Szurdokpüspöki - Hosszú-dúlö II-III. (M21 site No. 6-7)

Kristóf FüLÖP - Gábor VÁcZI

Preliminary report on the excavation of a new Late Bronze Age cemetery

from fobbágyi (North Hungary)

Lőrinc TimÁr - Zoltán CzAJLik - András BöDőcs - Sándor PuszTA

Geophysical prospection on the Pâture du Couvent (Bibracte, France). The campaign of 2014

Dávid BARtus - László Borhy - Gabriella Delbó - Emese SzÁmadó

Short report on the excavations in the civil town of Brigetio (Szőny-Vásártér) in 2014

Dávid BARTus - László BorHy - Emese SzÁMADó

A new Roman bath in the canabae of Brigetio

Short report on the excavations at the site Szőny-Dunapart in 2014

Dávid BARTus - László Borhy - Zoltán CzAjlik - Balázs Holl -

Sándor PuszTA - László RuPNiK

Topographical research in the canabae of Brigetio in 2014

Zoltán CZAJLIK - Sándor BERECKI - László RUPNIK

Aerial Geoarchaeological Survey in the Valleys of the Mureș and Arieș Rivers (2009-2013)

Maxim MoRDovin

Short report on the excavations in 2014 of the Department of Hungarian Medieval

and Early Modern Archaeology (Eötvös Loránd University, Budapest)

Excavations at Castles Čabrad' and Drégely, and at the Pauline Friary at Sáska

\section{Thesis Abstracts}

Piroska Csengeri

Late groups of the Alföld Linear Pottery culture in north-eastern Hungary

New results of the research in Borsod-Abaúj-Zemplén County

Ádám Bíró

Weapons in the 10-11th century Carpathian Basin

Studies in weapon technology and methodology - rigid bow applications and southern import

swords in the archaeological material

Márta DARÓcZI-SzABó

Animal remains from the mid 12th-13th century (Árpád Period) village of Kána, Hungary

Károly BELÉNYESY

A 15th-16th century cannon foundry workshop in Buda

Craftsmen and technology of cannon moulding and the transformation of military technology

from the Renaissance to the Post Medieval Period 
István RINGER

Manorial and urban manufactories in the 17th century in Sárospatak

\section{BIBLIOGRAPHY}

László BORHY

565

Bibliography of the excavations in Brigetio (1992-2014) 


\title{
A belső vámok szerepe a rajnai és a dunai provinciák importált kerámiaspektrumában
}

GABler DÉNES

denes.gabler@freemail.hu

\begin{abstract}
The political, strategical and cultural blocks in the Roman Empire functioned as economic units as well. The European provinces can be divided in two major groups: the Gaulish - Germanian provinces and the ones in the Danube valley. The economic development of these two areas differed significantly not only at certain points in time, but diverged all through the centuries of the Imperial period. The establishment of customs districts and the organisation of their administrative network played an important role in forming these economic units. Experience has provided evidence that the distribution of certain goods transported too far from their production areas can be recorded by the borders between customs districts. It can be contemplated that the markets may have been divided to facilitate the quick and efficient supply of the two main armies in Europe: namely in the Rhine region and in Illyricum. This supply could have been made possible by the clear distinction between shipments. A certain duality is apparent both in the spectrum of imported pottery and sources concerning the problem of which customs district Raetia belonged to? Some features in the composition of types within the imported material (Italian terra sigillata of the Tiberian-Claudian period, Sarius-ware, glazed Italian pottery, lamps, Raetian pottery) indicate strong economic ties with the Danubian provinces. Other ware however, reveals differences between the two areas (terra sigillata tardopadana, thin-walled pottery, amphorae, terra sigillata produced in Westerndorf or Pfaffenhofen). This contradiction should perhaps be explained by suggesting the change in customs borders by annexion of the province. That is, a customs district may be regarded as an economic unit and as such must be taken into consideration, when the distribution of several interprovincial types of finds is discussed.
\end{abstract}

Az eddigi kutatások eredményei azt bizonyítják, hogy a Róma által sokszor mesterségesen létrehozott közigazgatási egységek gyakran nem csak politikai-stratégiai, hanem kulturális ill. gazdasági tömbök kialakulásához vezettek. ${ }^{1}$ Ez nemcsak az import eredetének különbségében, tehát a kereskedelem irányában mérhető le, hanem a helyi ipar fejlődésében, termékspektrumában is, hiszen a helyi termelést az import jelentős mértékben befolyásolta. Ezeknek a helyi mühelyeknek termékei alig jutottak túl egy-egy provincia határán, de export radiusuk sokszor még ennél is kisebb. ${ }^{2}$

Az európai északi provinciáknál ebből a szempontból két nagyobb egység figyelhető meg: a galliai-germaniai ${ }^{3}$ és a dunai provinciák. Ezeknek a tömböknek gazdasági fejlődése a császárkor évszázadaiban jelentős különbségeket mutatott, amit eddig jórészt csak a fém- vagy az üvegiparban lehetett kimutatni. ${ }^{4}$ A kerámia tanúvallomása ezeknél azért jelentősebb, mert az áru eredete, mühelyei biztosabban határozhatók meg. Legszembetűnőbb a különbség az olyan importált kerámia esetében, amely a birodalom nagy részén elterjedt, sőt az Imperium Romanum határain túlra is eljutott. A gazdasági egységek fejlődésére a belső vámkörzetek

1 Schnurbein 1982, 15.

2 Petrikovits 1970, 385, 389. A legjelentősebb alsó-pannoniai műhely az aquincumi gázgyári fazekastelep piacterülete is csak Pannonia inferiorra terjedt ki, ha eltekintünk az egyetlen dorogi lelőhelyű darabtól, ld. GABLER 1976, 50. A gyártóhelytől legtávolabbi pont, ahová áruja eljutott Cibalae, ld. SARANOvić-SvETEK 1971, 175. Moesiában és Daciában ez az áru nem lelhető fel.

3 Petrikovits 1970, 403.

4 BARKóczi 1988, 40. 
kialakulása - megfelelő szervezettel, igazgatással - lényeges szerepet játszhatott. Míg koráb ban a vámkörzetek, vámhivatalok kérdésére a kutatók csak az epigráfiai, papyrologiai és más írásos források alapján keresték a választ, ${ }^{5}$ a kutatás jelenlegi állása mellett a régészeti források is megszólaltathatók. ${ }^{6}$ Több esetben megfigyelhető ugyanis, hogy egyes árufajták, tárgytípusok elterjedése csak az ismert vámkörzet határáig követhető. A vámkörzet határa eszerint, ha nem is árumegállító hatású, de olyan tényező, amely a határ két oldalán a kerámia spektrumát, eredetét és az egyes típusok arányát befolyásolja. A dunai provinciákat magába foglaló illyricumi vámkörzetet először Claudius korában említik forrásaink. ${ }^{7} \mathrm{Ha}$ a vámkörzet határainak pontos kijelölése és szervezetének kialakítása Claudius nevéhez fűződik is, joggal feltételezhető, hogy ez a szabályozás egy korábban már működő rendszerre épült. ${ }^{8}$ A quadragesima Galliarum kialakulása is az Augustus-kori vámpolitikára nyúlik vissza. ${ }^{9}$ Ebből a szempontból érdemes az Augustus-Tiberius-kori sigillata típusok elterjedésének tanulságait figyelembe venni. A kelet alpesi területeket ill. a dunai provinciákat az 1. század közepéig kizárólag Italia látta el terra sigillatával. Galliába és Germaniába, mind a rajnai mind a Rajnán túli katonai táborokba már Augustus korában jelentős mennyiségben szállított a lyoni műhely is, sőt - mint erre egy halterni fazekasmühely anyaga utalt ${ }^{10}$ - már ekkor megkísérelték az importot helyi áruval kiváltani.

\section{A nyugati és a dunai provinciákba szállító itáliai múhelyek}

A Duna-vidékre Lugdunum nem szállított, még a legfontosabb kereskedelmi centrumban, a Magdalensbergen is csak egyetlen vékonyfalú pohár képviseli a galliai manufakturát. ${ }^{11} \mathrm{~A}$ gallai-rajnai és a dunai provinciák kerámiaspektrumának lényeges különbségét azonban nem annyira a lyoni áru ill. utánzatainak megléte vagy hiánya mutatja, hanem elsősorban magának az itáliai kerámiának összetétele. Az észak-itáliai műhelyek, amelyek már Augus tus korában jelentős mennyiségben exportáltak Noricumba és Pannoniába, s amelyeknek termékei ennek megfelelően a dunai provinciák kerámia anyagában döntő mennyiségben találhatók meg, a galliai-germaniai tartományokban nem terjedtek el. ${ }^{12} \mathrm{~A}$ kerámia eredetének meghatározása ugyan sok esetben nehéz, mivel nemcsak a formák, de sokszor a bélyegek alapján sem tudjuk egyértelműen gyártóhelyhez kötni az egyes edénytöredékeket. Az eddig végzett természettudományos vizsgálatok azonban a fentieket, azaz az észak-itáliai áru hiányát igazolják a galliai-germaniai provinciákban. Újabb különbséget jelent a két terület itáliai sigillataspektrumában a puteoli műhely termékeinek teljes hiánya a Duna-vidéken. A magdalensbergi un. C Fabrikat, amelyet korábban ezzel a manufaktúrával hoztak kapcsolatba - mint utólag kiderült - az egyik Pó-vidéki gyártóhely minőségi jegyeit mutatja. ${ }^{13} \mathrm{~A}$ bélyegek alapján csak C. TAP( ) esetében jöhetett volna számításba a puteoli gyárhoz való attribuálás; annak négyszögletes bélyegei azonban a mi darabjainkkal semmilyen kapcsolatot sem mutatnak. Ennél az egyébként Savariában is fellelhető típusnál felmerült annak lehetősége,

5 DE LAET 1949; VitTinghoF 1953, 346-399; ǾRSTED 1985, 251-347.

6 Ulbert 1971, 109; GABler 1985, 3-29.

7 Dobó 1968.

8 ŠAŠEL 1965, 198; ǾRSTED 1989, 182.

9 France 1993, 895-927; France 2001, 449.

10 Schnurbein 1974, 77-88; Schnurbein 1977, 38-50.

11 Schindler-Kaudelka 1975, 176. A lyoni töredéken ívül csupán egyetlen dél-galliai és egyetlen hispaniai(?) töredék származtatható Italián kívüli műhelyből.

12 SCHNURBEIN 1982, 69.

13 SCHINDLER ET AL. 1997, 484. 
hogy a Pó-vidéki C ·T· S vagy C· T ·SUC mesterrel azonosítható a késő Pó-vidéki C. Tap ( ) bélyegeken szereplő gyártó ${ }^{14}$ a puteoli manufaktúra azonban semmiképpen sem vehető számításba. Ezzel szemben újabban derült ki, hogy egy vagy több ma még nem lokalizált középitáliai műhely is részt vett Pannonia ellátásában, ezek azonban elsősorban a Mediterraneumban és nem a nyugati provinciákban voltak érdekeltek. ${ }^{15}$ Galliai-germaniai területen jelentős Pisa aránya. ${ }^{16}$ A ma már lokalizált mühelyekben: Via Santo Stefano, via San Zeno, Isola di Migliarino elsősorban $\mathrm{Cn}$. Ateius felszabadított rabszolgái működtek, ${ }^{17}$ akiknek áruja a Duna-vidéken ismeretlen; a Magdalensbergen is csak két bélyeg köthető ennek a vállalkozónak valamelyik műhelyéhez (Atei Eros). A Pisából, méghozzá ugyanazokból az officinákból érkező ún. késő itáliai kerámia (L. Rasinius Pisanus, Sex. M. Fes, Sex. M. P) ugyanakkor Germaniában ismeretlen és Galliában is csak Narbonensis tengerparti sávjában lelhető fel. ${ }^{18}$

A különbségeket jól érzékelteti a magdalensbergi leletanyag, amelyben több mint 2400 bélyeges példány található. Ezek közül mindössze 13-14-re tehető azok száma. amelyeknek a galliai-germaniai területekről valamilyen párhuzamát ismerjük. Az említett Ateius bélyegeken kívül ezek közé tartozik a hosszú ideig működő P. Attius műhely, amelynek neussi példányai arezzói, ${ }^{19}$ halterni párhuzamai pisai gyártmányok ${ }^{20}$ ezzel szemben a magdalensbergi egy Pó-vidéki filialéhoz köthető. ${ }^{21} \mathrm{Az}$ arezzói L. Gellius Quadratusnak galliai-germaniai területeken csak korai, Augustus-kori gyártmányai ismertek, ezzel szemben a 212 magdalensbergi darabnak a nyugati területeken jóformán egyetlen egy párhuzama sincs. Az arezzói Memmius-mühely, amelynek gyártmányai Vindonissában, Dangstettenben, Neussban és Halternben gyakoriak, a Magdalensbergen alig ismert ${ }^{22}$ ugyanígy ritkán fordulnak elő L. Tettius Samia edényei is. ${ }^{23}$ A korai arezzói Saufeius-múhelyben dolgozó számos rabszolga közül a Magdalensbergen csak egynek a bélyege található meg. ${ }^{24}$ A galliai területek és a Magdalensberg "közös" bélyegeinél leggyakrabban az derül ki, hogy más-más gyártóhelyről származik az egyik ill. a másik területen található kerámia. Sertorius Ocella áruja pl. gyakori a Magdalensbergen, de ezek kivétel nélkül a Pó-vidéki B Fabrikat jegyeit mutatják; ezzel szemben a Baselben fellelhető példányok arezzóiak. Hasonló a helyzet A. Sestius Dama esetében is. Ennek magdalensbergi lelőhelyű példányai Pó-vidéki műhelyekhez köthetők, de tipológiailag is lényegesen különböznek a Neussban fellelhető bélyegtől. ${ }^{25}$ A. Titius arezzói mühelyének aránylag kevés gyártmánya ismert a Magdalensbergről, ${ }^{26}$ noha ott 20 példányon található meg ez a signatura. Jelentős részük azonban Pó-vidéki gyártmány vagy más mesterhez köthető. A. Vibius Figul(us) áruja mind a galliai-germaniai területeken, mind a Magdalensbergen ritka; ez a vállalkozás inkább a mediterraneumi szállításokban volt érdekelt. ${ }^{27}$

\footnotetext{
14 B. VÁgó 1977, 87, 108; Makjanić 1995, Fig.33, 38; Zabehlicky-Scheffenegger 1998, Abb. 25,1. A puteoli C. Tap( ) piacterülete Tarragonáig és Neussig terjedt, vö. OXE ET AL. 2000, 2036 a-f.

15 GABLER 2000, 16-25.

16 SCHNURBEIN 1982, 83; ETtLINGER 1983, 72.

17 KenRICK 1997, 185-188; BRUNi 1995, 271-461.

18 Brentchelof 1976; Giroussens 1998, 37; OxÉ Et Al. 2000, 1690, 165-166.

19 ETtLinger 1983, 52.

20 Megtalálhatók még Dangstettenben, Oberadenben, Xantenben, a Titelbergen és Mont Beuvray-n; ezek többnyire lyoni eredetű pédányok. Ld. Schnurbein 1982, 224, Nr.451; Oxe ET AL. 2000, 347, 74-75, 77, 56-57; ETTLINGER 1983, 53; FINGERLIN 1970-71, 197.

21 ZABEHLICKY-SCHEFFENEGGER 1991, 96.

22 Schindler - ScheffEnEgger 1977, Taf. 107; EtTllinger 1983, 58; ZABehlicky-SchefFEnEgGER $1982,105-115$.

23 SCHINDler - SchefFENEgGer 1977250.

24 EtTLINGER 1983, 94.

25 ZABEHLICKY-SCHEFFENEGger 1991, 97; EtTLINGER 1983, 96.

26 ZABEHLICKY-SCHEFFENEGGER 1998, 201.

27 EtTlinger 1983, 96.
} 
A figlinához tartozó Diomedes Vibi bélyeges példányai Neussban, Oberadenben és Dangstettenben gyakoriak; a Magdalensbergen ezzel szemben csak egyetlen, azokkal megegyező példány található. Az arezzói C. Umbricius Philologus ill. L. Umbricius különböző rabszolgáinak bélyegei Neusson kívül Oberadenben, Dangstettenben és Rödgenben is fellelhetők; közülük csak három található meg a Magdalensbergen. Az összehasonlító vizsgálat tehát azzal az eredménnyel járt, hogy a nagy mennyiségű itáliai sigillata bélyeg ellenére alig 5 százaléknyi átfedés mutatható ki a rajnai-galliai területek és a kelet alpesi-dunai provinciák leletanyagában. Még szembetűnőbb a különbség ha a galliai-germaniai tartományokban fellelhető itáliai bélyegeket a pannoniai emlékanyaggal hasonlítjuk össze.

A 132 ismert officinator közül csak a pisai P. Attius, az arezzói L.Tar(quitius), M. Perennius és Rasinius exportált mindkét területre. P. Attius esetében azonban nem lehetünk biztosak abban, hogy ugyanarról a figlináról van-e szó, mivel sem a sisciai,sem a zalalövői példányt eddig még nem vizsgálták analitikai módszerekkel, így nincs kizárva, hogy más filiálék látták el a pannoniai és mások a rajnai vagy a Rajnán túli táborokat. A magdalensbergi példányok vizsgálata azt mutatta, hogy a nagy kereskedelmi átrakóhelyre a Pó-vidéki leányvállalat szállított. ${ }^{28}$ Feltehető, hogy a jelentéktelenebb pannoniai piacra is innen jutott áru, és nem a távolabbi Pisából vagy Arezzoból. Az Umbricius-műhelyt is csak egy emonai darab képviseli (valamivel több található ebből a gyártmányból a Magdalensbergen, Linzben vagy az Auerbergen) ${ }^{29}$ és ugyanígy csak egy példány jutott L. Tar(quitius) figlinájából is a Maroboduus ellen felvonuló hadsereg bázisára, amely végül a dévényi erődített telep egyik objektumába került. A Halternből ismert 900 fazekasbélyeg közül csak három-négy azonos név fordul elő Pannoniában, de ezek is más-más officinatorokra vonatkoznak. Csak P. Attiusnál tételezhető fel, hogy ugyanattól a gyártótól, de más műhelyből hozták a sigillatát Sisciába ill. Halternbe. Ugyanígy Halternből ismerjük az arezzói M. Perennius bélyeg párhuzamát, amely Sisciában is megtalálható. Az arezzói C. Murrius edényei Sirmiumon kívül az Auerbergre is eljutottak. A Sisciában fellelhető Philo( ) vagy Philo bélyegnek egyetlen párhuzama ismert Neussból. ${ }^{30}$ A Rasinius műhely termékei aránylag gyakoriak a nyugati területeken, ugyanakkor Pannoniában csak Sirmiumból ismerjük ezt az árut. A Rasiniusoknak az arezzói műhelyükön kívül több filiáléjuk is volt, ezért a gyártóhely nehezen határozható meg. A Halternben talált darabot S.von Schnurbein a lyoni La Muette műhely gyártmányának tekinti. ${ }^{31}$

A rajnai-galliai területeken a leggyakoribb a $\mathrm{Cn}$. Ateius familiájához tartozó valamelyik rabszolga bélyegével jelzett arezzói, lyoni vagy pisai áru. Ezek közül Pannoniában egyetlen egy sem található. A Magyar Nemzeti Múzeum Cn. Ateius Ar(retinus) bélyeges sigillata tányérja ugyanakkor egy sokkal későbbi pisai műhely terméke, amely viszont a Rajna-vidékre nem jutott el. ${ }^{32}$ A nyugati provinciákban gyakran lelhető fel az Avilliusok műhelyének termékei, amelyek a dunai provinciákban nem találhatók meg; kivéve L. Avillius bélyegét, amely viszont a galliai-germaniai tartományokban ismeretlen. L. Gellius négyszögletes bélyegtípusai csak a nyugati területeken gyakoriak, a dunai tartományokban egyetlen egyszer sem fordulnak elő. A Noricumban és Pannoniában, valamint Moesiában fellelhető planta pedis keretelésű bélyegek ugyanakkor Rheingönheim kivételével ismeretlenek a galliai-germaniai területeken.

\footnotetext{
28 ZABEHLICKY-SCHEFFENEGGER 1991, 96-97.

29 OXe Et AL. 2000, 2441, 100-101; EttLinger 1983, 96; ZABehlicky-Scheffenegger 1998, 254-255, Abb. 28; RUPRECHTSBERGER 1983, 36.

30 ETtLINGER 1983, 58.

31 Schnurbein 1982, 103-104.

32 GABLER 2000, 16-20.
} 
Fentiek alapján arra következtethetünk, hogy a galliai-germaniai provinciákat és a keletalpesi-dunai tartományokat különböző manufaktúrák látták el áruval ill. ha azonos manufaktúrákból indították útnak a szállítmányokat (pl. Arretium), akkor más figlinákból érkezett kerámia a Rajna-vidékre és más műhelyből a Duna-vidékre; többnyire nem is ugyanabban az időszakban.

A gyártóhelyek ill. műhelyek különbségein kívül figyelemreméltó az időbeni eltérés a két területen megjelenő importnál. Míg a Rajna-vidéken az itáliai szállítmányok Augustus-koriak, vagy Tiberius uralkodásának elejére keltezhetők, a Duna-vidéken inkább Tiberius-Claudius korában érte el csúcspontját az itáliai import (Fig. 1). Nincs kizárva, hogy L. Gellius, L. Avillius és más vállalkozók az elvesztett nyugati piacok helyett az illyricumi területeken próbáltak meg új export területet szerezni. A nagy, szinte az egész Mediterraneumot ellátó gyárak, mint L. Gelliusé, Manneiusé, C. Me( )R( ), M. Perennius Crescensé, C. Ve( )Barg( ) vagy Villi usé mellett megfigyelhető néhány arezzói figlina, amely Italián kívül szinte csak Noricumba és Pannoniába szállított. Ilyen volt M. Perennius Saturninus vagy L. R( ) C( ) mühelye.

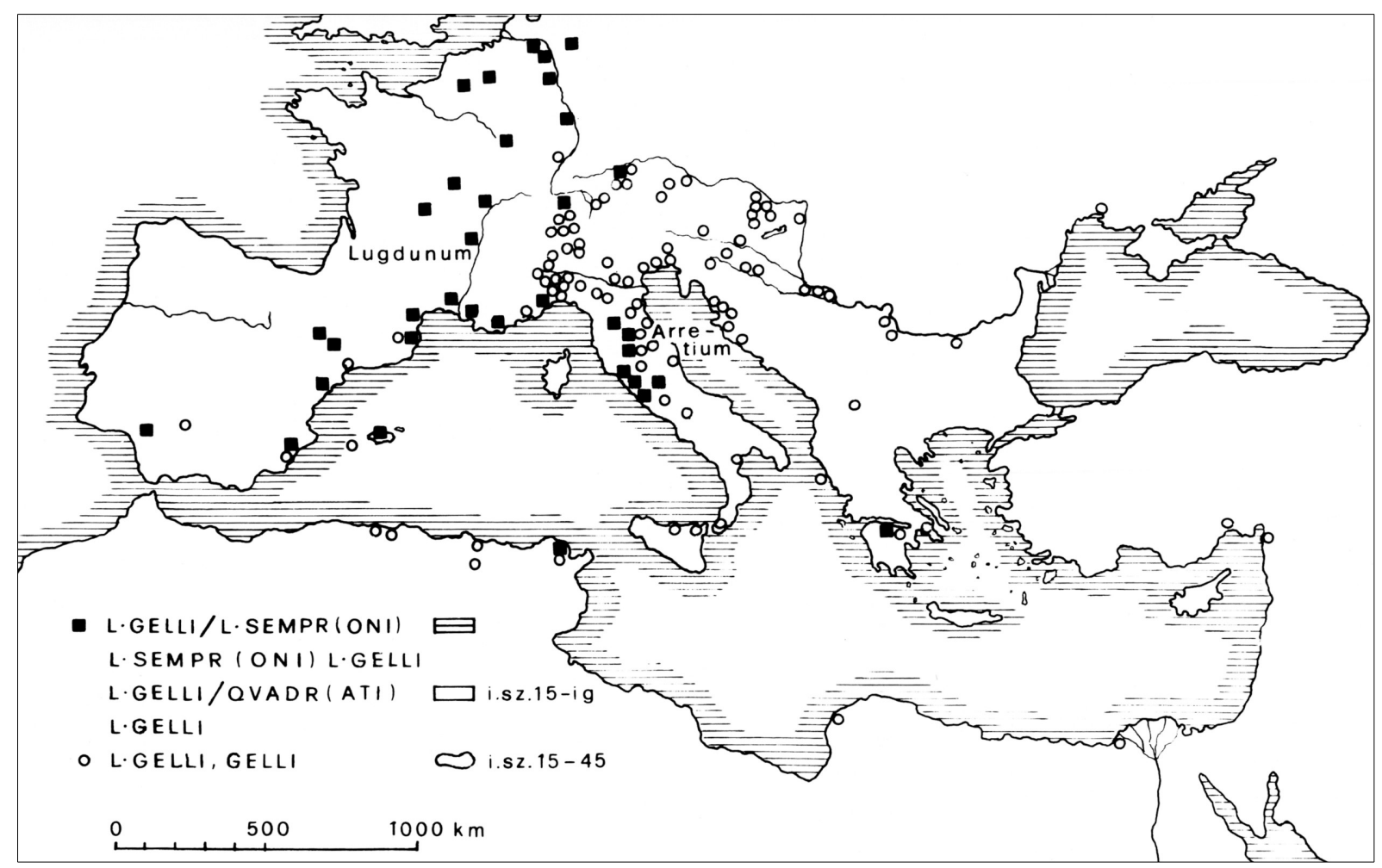

Fig. 1. L. Gellius műhelyének Augustus-kori (négyszögekkel jelölt) és Tiberius-Claudius kori (körökkel jelölt) lelőhelyei.

Az itáliai sigillata bélyegek döntő többsége észak-itáliai gyártóhelyek officinatorait jelöli; legtöbbjüknek áruja Észak-Itálián kívül csak a Duna-vidéken lelhető fel. Aránylag sok keltezhető közülük Augustus-Tiberius korára. Figyelemre méltó két nagy vállalkozás termékeinek szóródása, amelyek ismét a két nagy tömb közötti különbségre hívják fel a figyelmet. A Vettiusok sigillatái az egész Mediterraneumban fellelhetők, Pannoniában azonban nem találhatók meg. A sisciai, carnuntumi és dévényi bélyegekről ismert M. Vettius név ugyanakkor Pannonián kívül nem fordul elő. A másik nagy vállalkozó C. Sentius, akinek itáliai gyára 
mellett Lyonban és Kisázsiában volt leányvállalata, ${ }^{33}$ Pannoniába nem exportált. A firma másik tagjának nevével jelzett Augustus-kori sigillatát (M.Sentius Sex( )) ugyanakkor csak a Magdalensbergről és a Kapos völgyéből ismerjük.

Fentiek arra utalnak, hogy már Augustus korában számolhatunk olyan mủhelyekkel, amelyek kifejezetten a dunai ill. a galliai-rajnai piacok részére termeltek. Még a nagyobb, az egész Mediterraneumot ellátó manufaktúrák esetében is jól elkülöníthetők a rajnai provinciákba vagy az Illyricumba exportáló figlinák. Csak ritkán fordul elő, hogy ugyanabból a fazekasműhelyből mindkét területre egyaránt szállítanak, de ezek szinte rendkívüli esetnek tekinthetők (pl. a Maroboduus elleni felvonulás idején került Dévénybe olyan arezzzoi műhely áruja, amely a nyugati területeket látta el (ld. L. Tar(quitius)) Az illyricumi hadsereg támaszpontjának számító Sisciában pl. a mindkét területet ellátó gyártók bélyegeinek részesedése alig 2 százalék, ha P. Attius "közös" szállítónak tekinthető.

Míg tehát Arezzo és Pisa Augustus korában a mediterraneumi piacokon kívül a galliai-germaniai táborokat, településeket látta el, a kelet alpesi-dunai területekre többnyire a Pó-vidéki műhelyek szállítottak. Tiberius - Claudius korában a növekvő kereslet miatt Arretium és részben Pisa drágább termékei is utat találtak Illyricum felé, ugyanakkor az etruriai manufaktúrák elveszítették nyugati piacaikat.

\section{A nyugati és a dunai provinciák kerámiaspektrumának eltérései az Aco-Sarius típusok kapcsán}

A sigillata anyag elemzéséből levonható következtetések irányába mutatnak azok a megfigyelések is, amelyeket a vékonyfalú kerámia egyik sajátos csoportjának, az ún. Aco-Becher elterjedésének vizsgálata kapcsán $M$. Vegas tett. ${ }^{34}$ A bélyeges példányok megoszlása itt is eltérő. Galliában és Germaniában az Aco officinák közül Hilarus Aco, Chrysippusés Philarcurus, C. Avius, T. C. Avius valamint Philocrat(us) szállított, míg Aco Acastus, Aco Diophanes, C. Aco Antiochus, C. Aco C. 1. Eros, Buccio Norbani, Antiochus, Gellius Antiochus és Agatho Észak-Itálián kívül a Magdalensberget, Észak-Dalmáciát és részben Pannoniát látta el áruval. ${ }^{35}$. A két piacterületen tehát a vállalkozó különböző libertus-officinatorainak bélyegei tűnnek fel, akik igyekeztek a piacterülethez közel berendezni mühelyeiket. A galliai területeket Aco lyoni filialéjából látták el, ${ }^{36}$, míg Észak-Itáliában és a dunai tartományokban több, a Póvölgyének nyugati részén, továbbá egy Cremonában ${ }^{37}$ és egy Faenzában ${ }^{38}$ működő műhely gyártmányai terjedtek el. ${ }^{39} \mathrm{~A}$ kétféle áru piacterületén némi átfedés mutatható ki, amit $\mathrm{M}$. Vegas azzal magyarázott, hogy ezek személyes felszerelésként érkezhettek a másik gyártóhely(ek) piacterületeire. Raetia mind a nyugati területekre jellemző Chrysippus áru, mind az Augsburg-Oberhausenben vagy a Lorenzbergen fellelhető vékonyfalú kerámiatípusok alapján a galliai-germaniai területek spektrumának sajátosságait mutatja ${ }^{40}$ Korábban K. Kraft meggyőző érvekkel bizonyította, hogy Raetia Augustus korában a rajnai hadsereg parancsnoksága

33 A Vettiusokhoz ld. Oxe Et AL. 2000, 2113-2124. M. Vettius árujához Gabler 1981, 12. C. Sentius mühelyéhez ld. ZABEHLICKY-SCHEFFENEGGER 1995, 257.

34 Vegas 1969-70, 107-117.

35 SChindler-KaUdelKa 1980, 83; MAKJANić 1995, 61; Finocchiaro 1999, 146-159.

36 Vertet ET AL. 1968, 35-44.

37 STENICO 1963-64, 51-59.

38 Righini 1979, 213-240.

39 LAVIZZARI-PEDRAZZINI 1987, 43-47.

40 Vegas 1969-70, 114; Ulbert 1959, 59. 
alá volt rendelve; ennek a katonai körzetnek határa az Inn-folyónál végződött. ${ }^{41} \mathrm{Kraft}$ szerint ez a stratégiai-katonai körzet egyben gazdasági hovatartozást is jelentett, mivel AugsburgOberhausen és Kempten éremanyagában Lugdunum és Nemausus veretei gyakoriak, míg a távolabbi noricumi területeken ezek szinte hiányoznak. ${ }^{42}$ A gazdasági egységek kialakulásának folyamata tehát már Augustus korában megkezdődhetett, ${ }^{43} \mathrm{~s}$ ha Kraft gondolatmenetét követjük, akkor a háttérben a két jelentős hadsereg, a rajnai és a dunai legiok gyors és problémamentes ellátásának igénye állhatott, amely a szállítási feladatok, kötelezettségek világos megosztását eredményezte. Az import, az utánpótlás forrása a Tiberius - Claudius korban is különböző volt. Gallia, Germania, Britannia piacait már ekkor Montans és La Graufesnque árui uralták, míg a a kelet alpesi-dunai tartományokban továbbra is monopolhelyzetet élveztek az észak-itáliai, arezzói és részben más itáliai műhelyek. Leginkább az arezzói L. Gellius planta pedis keretelésủ bélyeges sigillatáinak elterjedéséből olvasható ki a piacterületek megosztásának és az abban végbemenő változásoknak tendenciái. A nyugati exportjának elvesztésével ez a vállalkozás nemcsak a Magdalensbergen talált piacot, hanem a Duna-menti előretolt táborokban és azok utánpótlási vonalai mentén épült állomásokon, telepeken is: mind Raetiában és Noricumban, Pannoniában és Moesiában.

Raetia ellátásában még jelentős Italia szerepe, amit nemcsak a Gellius áru elterjedése bizonyít, hanem az ún. Sarius kerámia is. Ez az árufajta nem található meg a nyugati provinciákban; számuk Italiában is csak az északi területeken, valamint Aquileia környékén jelentős. ${ }^{4}$ Italián kívül csak a dunai tartományokba szállították az ún. Sarius Tasse-t; ennek számos példánya ismert a Magdalensbergről, az Adria keleti partvidékéről és az Alpok előteréből; a Lorenzbergről és az Auerbergről. ${ }^{45}$ Nyugat Pannoniából (Nauportus, Emona, Neviodunum, Sirmium, Salla, Carnuntum). ${ }^{46}$ A Sarius-kerámia fénykora Augustus uralkodásának idejére tehető, gyártása azonban Tiberius-Claudius korában is folytatódott. ${ }^{47}$ A piacterületek eltérése látható a formatálból kialakított vagy barbotinnal díszített kisázsiai mázas kerámia északitáliai vagy provinciális utánzatainak elterjedéséből is. ${ }^{48}$ A Tarsusból származó áru mind Északnyugat-Itáliában, a keleti Alpok vidékén (Magdalensberg), mind az Alpok előterében megtalálható (Vindonissa, Kempten); a kisázsiai importot általában mindenütt helyi áru váltotta fel. ${ }^{49}$ A nyugati provinciákban ez a kerámiai galliai manufaktúrákban készült; gyártásuk szorosan összefügg a sigillatákéval. Az észak-itáliai fazekasműhelyekben már aránylag korán megkezdődött a mázas kerámia gyártása. ${ }^{50}$ Ezek a ma még nem lokalizált gyártóhelyek, ugyanúgy mint a korabeli sigillaták, az Aco- vagy a Sarius-kerámia mühelyei főként az Alpok vidékére ill. az Alpok előterébe szállították árujukat ${ }^{51}$, egyfelől Vindonissán és Bregenzen Cambodunumba, az Auerbergre és Aislingenbe, másfelől a Magdalensbergre és Carnuntumba; Carnuntum közvetítésével pedig a közeli barbaricumi területekre. ${ }^{52}$ A nyugati provinciákban

41 KRAFT 1962, 150.

42 Kraft 1962, 152, Anm. 31.

43 France 1993, 895-927.

44 LaVizZari-Pedrazzini 2000, 365-367.

45 Ulbert 1965, 68; Schindler-Kaudelka 1980, 103; MakJanić 1981, 54.

46 GABLER 1985, 10.

47 Klumbach 1966, 180-182.

48 De LucA 2000, 129-130; Hochuli-Gysel 1976, 226-241.

49 Hochuli-Gysel 1977.

50 MACCABRUNi 1994, 49-61; BRECCIAROLI TABORELLI 2000.

51 Schindler-KaudelKa 1980, 98; MACCABruni 1981; MACCABruni 1985, 16.

52 A vékonyfalú kerámiához ld. Marabini Moevs 1973, 211-244; Bergamini 1973, 19; Ricci 1985, 349; SchindlerKAUDELKA 1998, 395; A barbaricumi példányokhoz ld. KolniK 1980, 99, 108, 111, 114, 125, 131, 139, 157. 
az észak-itáliai mázas kerámia is ismeretlen. A mázas edényeknek a sigillatákkal ill. az Acokerámiával való összefüggéseit az is bizonyítja, hogy az Aco-poharak között mázas példány is található.

A fentiek alapján logikusnak tűnik, hogy olyan mezőgazdasági termékek mint az olaj, bor, gyümölcsök, tengeri termékek döntő mértékben Itáliából érkeztek a Kr.u. 1. században. ${ }^{53}$ A Noricumba és Pannoniába szállító vállalkozók amphora bélyegei Galliában és a Rajnavidéken szinte ismeretlenek, ugyanakkor a Földközi tenger medencéjében gyakran feltűnnek. Késő-köztársaságkori itáliai amphorák (Dressel 1, Lamboglia 2) - egy gellérthegyi példány kivételével ${ }^{54}$ - csak a Dráva-Száva közén lelhetők fel, ${ }^{55}$ ezzel szemben a Dressel 6A és $\mathrm{B}^{56}$ típusok az Italiához közeleső területeken kívül már a borostyánút mentén ${ }^{57}$ és részben a Dunakanyarban is megtalálhatók. ${ }^{58}$ Noricumot és Pannoniát főként Calvia Crispinilla, $\mathrm{P}$. Iturius Sabinus, C. Laekanius Bassus és fiának istriai birtokáról látták el olivaolajjal. ${ }^{59} \mathrm{~A}$ bélyegek részben a senator vilicusaira ill. officinatoraira vonatkoznak.

A rajnai táborokat már Augustus korában Hispaniából látták el olajjal és halszósszal, s noha a bort eleinte még Itáliából importálhatták, a rajnai és a dunai provinciák amphora bélyegei nem egyeznek. Ez azt jelenti, hogy vagy más vállalkozók vehettek részt az egyik vagy a má sik területre irányuló exportban, vagy különböző időben érkezhettek az itáliai szállítmányok. ${ }^{60}$ A galliai borok már a Flavius korban konkurenciát jelentettek. Pannoniában Kr. u. 1. században még jelentéktelen a hispaniai bor - Vindobonából ismerünk Tarraconensisből származó Dressel 2-4 formájú amphorát ${ }^{61}$ - vagy garum importot (Beltrán I és IIA típusú amphorák) ${ }^{62}$ de a 2. századtól kezdve Hispania jelentősége szinte meghatározó. ${ }^{63}$

\section{A nyugati és a dunai provinciák leletanyagának eltérései Claudius korától}

Az eddigiek alátámasztják azt a feltevést, hogy már Claudius kora előtt import szempontjából határozottan elkülönültek a galliai-rajnai és a dunavidéki területek. Raetia inkább a nyugati gazdasági egységhez tartozhatott, bár Tiberius-Claudius korában ide még jelentősebb mennyiségben szállítanak az itáliai sigillatagyárak és más fazekasműhelyek. Itt azonban - szemben a többi illyricumi tartománnyal - már hamar feltűnnek a dél-galliai ipar termékei.

Míg a Claudius kor előtt csak feltételezheto, hogy egyes árucikkek elterjedését a vámkörzet határánál szedett vám befolyásolhatta, a Claudius kor utáni típusok elterjedésénél ez igazolható.A Kr. u. 1. század második felére ill. a 2. század elejére keltezhető itáliai sigillaták elterjedésének nyugati határa az Inn, Raetia és Noricum, azaz a publicum portorium Illyrici és a quadragesima Galliarum határa (Fig. 2). Míg az Inntől nyugatra Claudius uralkodását követően az itáliai áru hiányzik, az Inntől keletre a Flaviusok koráig a dél-galliai sigillaták mennyisége jelentéktelen.

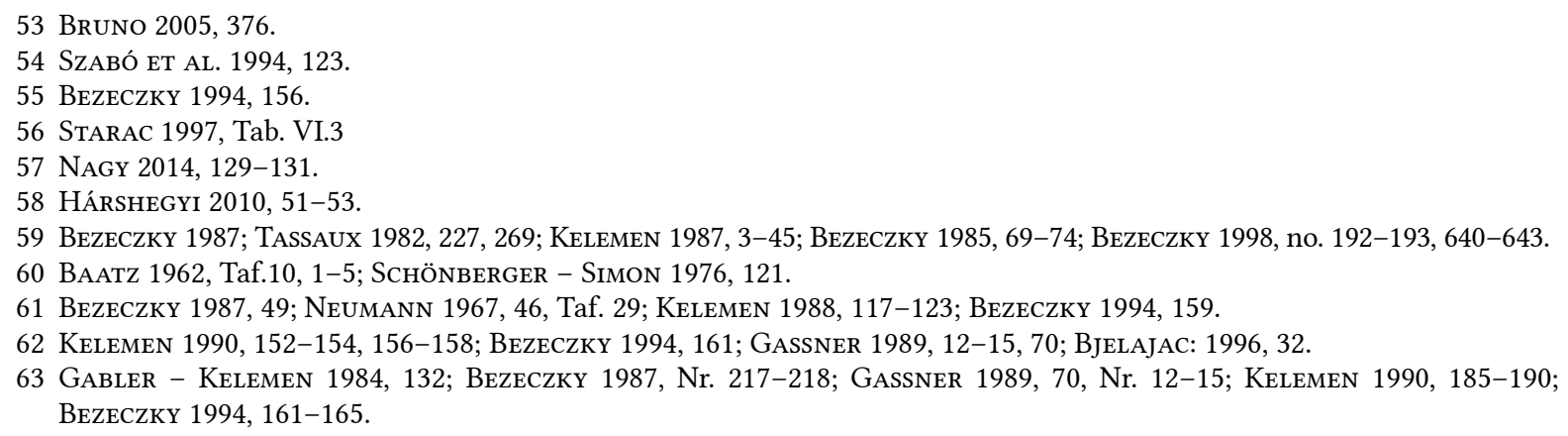


Ez nyilván nem a szállítási nehézségekkel magyarázható, mivel ha az itáliai áru az Alpokon már túljutott, mint ezt Iuvavum, a bajorországi Seebruck, Reichenhall, Marzoll, Karlstein, Tittmoning vagy Hörafing leletei igazolják ${ }^{64}$ a nyugat felé elterjedését csak a dél-galliai sigillaták konkurenciája akadályozhatta. Ez a kerámia Raetiába még vámmentesen érkezett, de az Inntől keletre történő szállításukat az aránylag magas illyricumi vám (12,5\%) akadályozhatta. ${ }^{65} \mathrm{~A}$ keleti területekre tehát az itáliai áru olcsóbbnak bizonyult, ezért La Graufesenque itt alig jelentett konkurenciát. Az itáliai ipar termékeinek hosszú ideig tartó monopóliuma és a dél-galliai sigillaták szórványos felbukkanása tehát az aránylag magas illyricumi vámnak köszönhető, vagy legalábbis a vámtarifa a kerámia árát döntően befolyásolta.

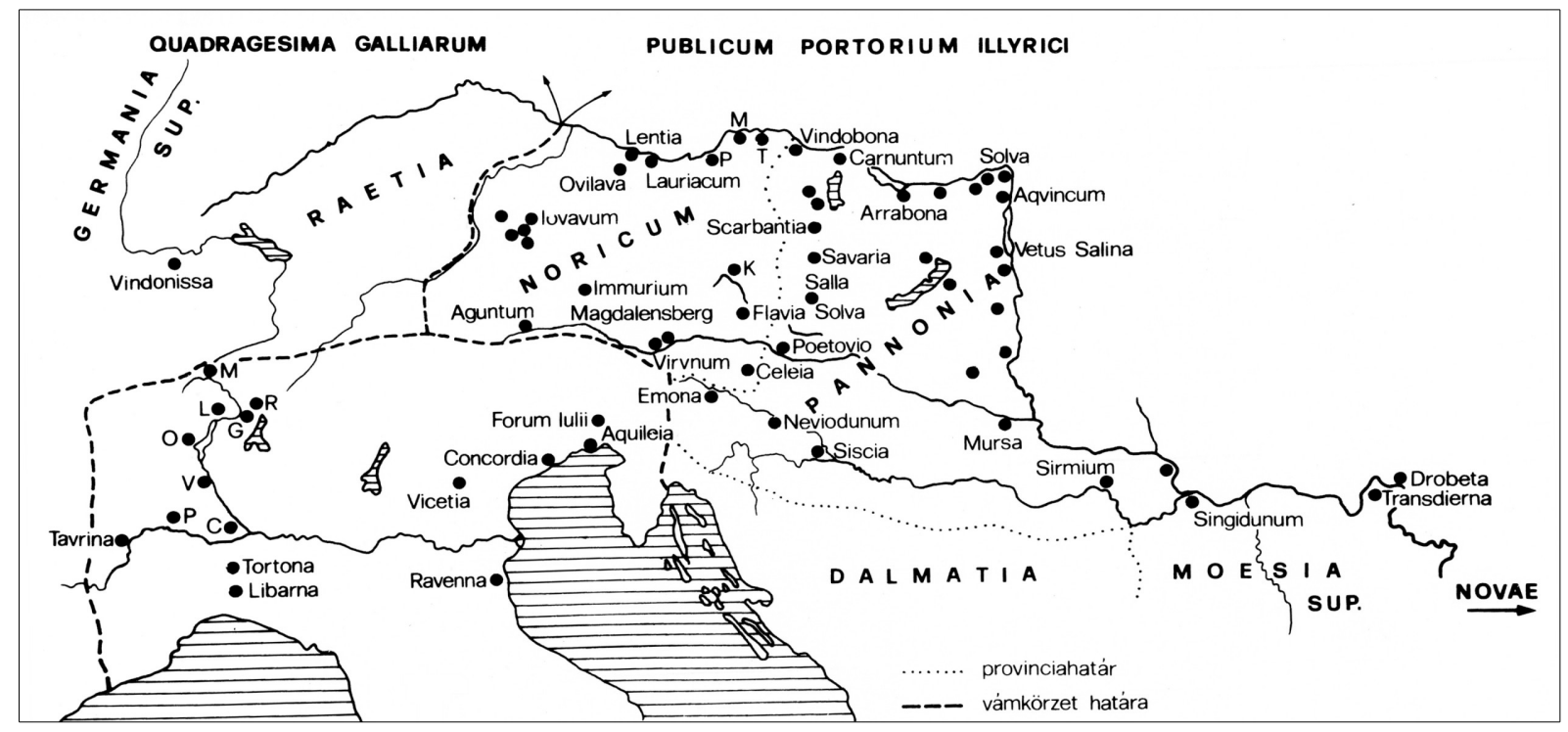

Fig. 2. A Claudius - Flavius-kori észak-itáliai sigillaták lelőhelyei.

Az itáliai export kedvező helyzetének köszönhető az ún. késő itáliai reliefdíszű áru pannoniai és részben moesiai elterjedése is, noha ennek gyártóhelye Pisa ${ }^{66}$ már távolabb volt a dunai tartományoktól. L. Rasinius Pisanus, Sex. Mur(rius) Pi(sanus), C.P. Pi(sanus) és a többi „késő itáliai” mester Domitianus korától szállított sigillatát Italia egész területére, Hispaniába, Észak-Afrikába; Galliának azonban csak mediterraneumi sávjában lelhetők fel ezek a típusok, ${ }^{67}$ míg Germaniában hiányoznak. Síregyüttesek adatai utalnak arra, hogy ez a pisai áru legalább Hadrianus koráig még a dunai tartományokban is versenyképes volt az erősödő dél-galliai áruval szemben. Az itáliai sigillata gyárak még Traianus korában (vagy az után is?) aránylag jelentős mennyiségben exportáltak mind Noricumba, mind Pannoniába, mint azt a Consp. 39 és Consp.43 típusok széleskörű elterjedése bizonyítja. ${ }^{68}$

A galliai-germaniai provinciákkal ellentétben a Duna-vidéken az itáliai vékonyfalú kerámia elterjedése jóval hosszabb ideig, legalább Trajanus koráig követhető, de egyes típusok még a 2. század közepére keltezhető leletegyüttesekben is megtalálhatók. ${ }^{69}$ Mint gyártóhely, Cremona, Ravenna és Aquileia jöhet számításba. ${ }^{70}$ Noha újabb adatok arra utalnak, hogy Emonában és Sirmiumban ${ }^{71}$ is

\footnotetext{
64 GABLER 1985, 15, 22.

65 Mócsy 1962, 595; Két brigetioi felirat is információt ad a vám mértékéről ld. CIL III 4288=RIU II.389, RIU 575; ld. továbbá Buócz 1969, 300-304.

66 Pucci 1974, 1-4; Menchelli 1994, 9-34; Menchelli 1995, 333-350; Cherubini - Del Rio $1997,133-141$.

67 GUÉRY 1987, 131-136.

68 Gabler 1991, 246; Gabler 1990, 150-151; Bauer 1998, 37; Gabler 2001, 117.

69 GASSNER 1990, 268.

70 Sena Chiesa 1979, 58; Maioli 1972-73, 106; Maselli Scotti 1984, 54; Gervasini 2005, 305; Faga $2011,148$.

71 Premk 1987, 437; PlesniČAR-Gec 1987, 454; Istenić - PlesniČAR-Gec 2001, 738.
} 
gyártottak itáliai mintára vékonyfalú kerámiát, nehézségeink vannak ezek keltezésével, és nem tudjuk, hogy ezek a termékek milyen arányban vannak jelen a pannoniai leletanyagban. ${ }^{72} \mathrm{~A}$ galliai-germania provinciákat már az 1. század első felétől kezdve Lyon, La Butte vagy más germaniai gyártóhely látta el vékonyfalú kerámiával $;^{73}$ ez az áru a déli területeken már Augustus korában megtalálható.

A rajnai és a dunai provinciák importja, valamint az abból kifejlődő helyi gyártás lényegesen különbözik a mécsesek esetében is. A dunai provinciákban az 1. században az import kizárólag itáliai, amelyet az 1. század második felében egyre inkább felváltanak az itáliai minták alapján működő helyi műhelyek. A. Leibundgut szerint Észak-Italia, Raetia és a dunai provinciák a Loeschcke I és a Loeschcke $\mathrm{X}$ formájú mécsesekkel tipológiai szempontból egy nagyobb egységet alkotnak, ${ }^{74}$ míg a Rajna-vidéken a helyi üzemekben a prototípusoktól eltérő gyártmányok fejlődtek tovább. Schnurbein hívta fel a figyelmet arra, hogy a firmamécsesek esetében pl. Germaniában csak a füles változatot gyártották, míg a Duna-vidéken - kevés kivételtől eltekintve - a fül nélküli példányok jelentek meg, ${ }^{75}$ noha mindkét típus széles körben elterjedt volt. A két tömb között átfedés az elterjedésben alig észlelhető. A két típus elterjedésének határa Germania superior és Raetia határával esik egybe. A firmamécsesek esetében még egy lényeges különbség figyelhető meg, mégpedig a névbélyegeknél. Néhány gyakori fazekas jelzéstől, mint Communis, Fortis, Strobilis eltekintve, a Rajnavidéken egészen más nevek fordulnak elő mint a Dunavidéken, ${ }^{76}$ feltehetően azért, mert korábban egyes észak-itáliai vállalkozók kifejezetten az illyricumi provinciákba, mások a Rajnavidékre exportálhattak. ${ }^{77} \mathrm{~A}$ helyi gyártás kialakulását és további fejlődését azok az itáliai anyavállalatok befolyásolták, amelyek korábban az adott területre szállítottak, ezek nyitottak filialét, adtak el modeleket vagy mủhelyfelszerelést. Deringerrel szemben már A. Neumann hangsúlyozta, hogy nem csupán névvel együtt történő másolásról, leformázásról, utánzásról van szó, ${ }^{78}$ annak ellenére, hogy a márkavédelem az ókorban ismeretlen. Véleménye szerint az itáliai vállalkozó eleinte valamilyen módon a helyi gyártást is befolyásolhatta, ahhoz nevét adhatta. A provinciabeli fazekas legfeljebb később függetleníthette magát az itáliai gyártótól.

Schnurbein a fenti megfigyelések sorát egy továbbival gazdagította. Kimutatta, hogy a 2 . századra jellemző, bevonatos ivópoharak esetében Raetiában és Germania superiorban, tehát két szomszédos provinciában, lényeges különbséget észlelhetünk. Az ún. raetiai kerámia pl. a Neckar vidéken rendkívül ritka. ${ }^{79}$ A Raetiához közeli Köngen és Welzheim kivételével a legkorábbi típusok, a Drexel 1 csoport a felsőgermaniai limesen sehol sem lelhető fel, ugyanakkor kelet felé a Duna mentén ennek a kerámiának elterjedése Noricumban és Pannoniában egészen a Dráva torkolatvidékéig követhető, sőt még a barbaricumba is eljutott. ${ }^{80}$ Schnurbein ezen keresztül is a szomszédos provinciák kultúrtörténeti helyzetének különbségét hangsúlyozta, és azt számos argumentummal támasztotta alá.

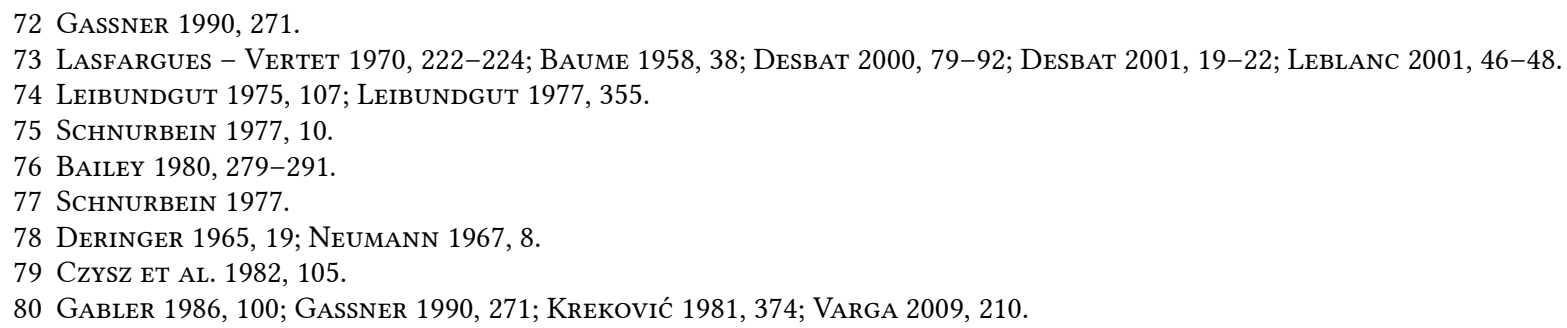




\section{A vámkerületek határai és átszervezései}

Az említett párhuzamosságok Raetiának a dunai tartományokkal való összefüggéseire utalnak, ami arra vitára irányítja a figyelmet, amely Raetia vámkerületi hovatartozásának kérdése körül folyt. A korábbi javaslatokkal ellentétben, amelyek részben egyik vagy másik javára döntöttek, vagy kompromisszumokat kerestek, a magam részéről hipotézisként vetném fel annak lehetőségét, hogy a Raetia és Noricum-Pannonia kerámiaspektrumában az 1. század végétől a 2. század közepéig megfigyelhető közös vonások ill. a lényeges különbségek hiánya esetleg azzal magyarázható, hogy Raetia a 2. században hosszabb időn át a publicum portorium Illyrici-hez tartozhatott.

Erre utalna különben Appianosnak a vitát és bizonytalanságot kiváltó adata is, amely szerint az illyricumi vámkörzet a Duna forrásától a Tyrasnak Fekete-tengeri torkolatáig terjedt (III.3.6). Ha ennek az adatnak érvényességét a 2. század középső harmadára vonatkozólag elfogadjuk, érthetővé válik, hogy néhány interprovinciális kerámiatípus elterjedésének határa miért esik egybe Raetia és Felső-Germania határával. Éppígy megfigyelhető a vámkörzet határának és a galliai-germaniai sigillaták elterjedésének határ egybeesése a borostyánút mentén. Noha ezek a sigillata-típusok váltakozó gyakorisággal a Duna torkolatáig mindenhol megtalálhatók a dunai tartományokban, mégsem lelhetők fel Emonában és annak territoriumán. ${ }^{81}$ Miután Noricum déli részén, Flavia Solvában, ${ }^{82}$ Aguntumban vagy Celeiában $^{83}$ a nyugati sigillata gyárak termékei még aránylag jelentős mennyiségben találhatók meg - ugyanakkor Celeia és Emona közötti vámállomástól, sőt a vámkerület határát jelentő Ad Publicanostól délnyugatra szinte egyáltalán nem - joggal gyanítható, hogy a galliai-germaniai áru elterjedését itt is az illyricumi vám állította meg. Emona, amely a 2. században már mindenképpen Italia $X$ regiojához tartozhatott, a sigillatákat Italiából szerezte be vagy esetleg helyi mühelyekből. Plinius adata szerint Emona Pannoniához tartozott (Nat. Hist. III.147), de lehet, hogy Vespasianus korában megtörténhetett az átcsatolás. ${ }^{84}$ P. Ǿrsted szerint a statio portorii-t éppen az 1. század 80-as éveiben állíthatták fel a Trojana hágó előtt (Watsch-Vače), majd később, Antoninus Pius korában Atransba helyezhették át. ${ }^{85}$

Raetia és a dunai provinciák kultúrájának közös vonásai a 2. században a legmarkánsabbak. A 2. század végén, vagy a 3. század elején Raetiát valószínüleg a galliai vámkörzethez csatolhatták át, talán a vámügyek Commodus kori átszervezése, közvetlen állami kezelésbe vétele kapcsán, ${ }^{86}$ akkor ezek a korai spektrumot jellemző közös vonások eltűnnek, és ismét az eltérések jellemzik a két szomszédos tartomány Raetia és Noricum anyagi kultúráját. A legszembetűnőbb különbség a westerndorfi-pfaffenhofeni áru elterjedésében mutatkozik. Ezek a jelentősebb gyártóhelyek, amelyek éppen a két tartomány határán jöttek létre a 170-es évek közepe táján, áruikkal szinte elárasztották a dunai provinciákat, egészen a folyó torkolatvidékéig ${ }^{87}$ (westerndorfi sigillaták feltűnnek olyan lelőhelyeken mint Durostorum, ${ }^{88}$ Barboşi $^{89}$ vagy Nicopolis ad Istrum, ${ }^{90}$ és nagy számban lelhetők fel a Pannoniával szomszédos Barbaricumban),

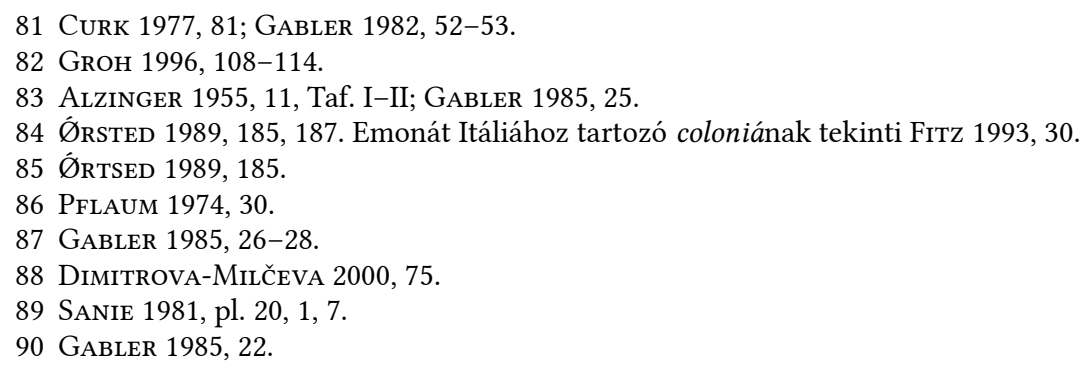


ugyanakkor az Inntől nyugatra csak néhány lelőhelyét ismerjük és mennyiségük ezeken is minimális, annak ellenére, hogy ezek a területek a mühelyhez közel fekszenek ${ }^{91}$ (Fig. 3). Ennek alapján G. Ulbert már korábban feltételezte, hogy a két provincia, azaz a vámkörzetek határa közvetlenül Westerndorftól nyugatra húzódhatott, ami azt jelenti, hogy a manufaktúra müködése idején Raetiát már a quadragesima Galliarum-hoz csatolhatták. ${ }^{92}$ Nincs kizárva, hogy a későbbi raetiai áru (Drexel II-III csoport) azért tűnik fel gyakrabban Germania superiorban és ritkábban Pannoniában - különösen a Drexel III csoport - mert az új vámhatár, amely a nyugat felé irányuló exportnak kedvezett, kelet felé mindenképpen akadályt jelenthetett. A nyugat felé történő piacbővítés azonban mindenképpen figyelemreméltó, hiszen itt olyan gyárak konkurenciájával kellett megküzdeni, mint a trieri kerámiamühelyek. ${ }^{93}$ Mindaddig azonban míg a raetiai kerámia átfogó feldolgozására, a teljes anyagfelvételre, az egyes műhelyek időrendjének, export radiusának meghatározására nem kerül sor, az itt megfogalmazottak csak munkahipotézisnek tekinthetők. Ez a hipotézis mindamellett megalapozott, amit egy Westerndorfban feltárt, a sigillata mellett raetiai kerámiát is gyártó műhely is bizo nyít. ${ }^{94} \mathrm{Ez}$ a fazekasüzem a legkésőbbi, a 2. század közepétől a 3. század első évtizedeiig terjedő időszakra keltezhető Drexel III csoportba sorolható „raetiai” kerámiát gyártotta, ami azt jelenti, hogy az egyes vállalkozók megpróbálták az illyricumi vámot kiiktatva szerezni piacot kelet felé, azaz a 2. század utolsó harmadától már vámmal is megdrágult importot helyi áruval felváltani. ${ }^{95}$ A pannoniai mühelyek, amelyek a raetiai kerámiát utánozták, pontosabban nem keltezhetők; minden valószínűség szerint azonban ezek is a 2. század végétől, vagy a 3. század elejétől egyre ritkább importárut akarták felváltani. ${ }^{96}$ A raetiai áru helyi, pannoniai gyártása ettől az időszaktól kezdve meghatározó jelentőségű; ${ }^{97}$ nem tekinthető csupán marginális jelentőségű kísérletnek.

Mind a kerámiaanyag párhuzamaira, mind Raetia vámkörzeti hovatartozására vonatkozó adatok ellentmondásosak: a kerámiaspektrum egyes elemei a dunai provinciákéval egyeznek meg (pl. Tiberius - Claudius kori itáliai sigillaták, a Sarius Tasse, az észak-itáliai mázas kerámia, a mécsesek, a legkorábbi raetiai kerámia), ugyanakkor más típusok a dunai tartományokéval szembeni különbségekre utalnak (a későbbi italiai sigillaták, vékonyfalú kerámia, amphorák, westerndorfi-pfaffenhofeni sigillaták, trieri áru stb.). Az ebből a kettősségből fakadó ellentmondás azonban talán feloldható, ha feltételezzük a vámkerület átszervezésével való összefüggését. Noha a vámszervezet átalakítása körüli vita még nem zárult le, feltételezhető, hogy az egyezések egy adott időszakban közös vámkerületre, a más időpontokban megfigyelhető különbségek viszont a Raetia és Noricum között húzódó vámhatárra utalhatnak. Valószínủ tehát, hogy a vámkerület olyan gazdasági egység lehetett, amely interprovinciális lelettípusok elterjedésének vizsgálatánál nem hagyható figyelmen kívül.

A késő-Flavius kortól a Duna-vidéken is jelentős a galliai sigillaták importja éppúgy mint más nyugati árucikkek behozatala. Ezeknek elterjedése elsősorban a Duna-völgyében, a limestáborok körzetében figyelhető meg. Minthogy a hadseregnek történő szállítás vámmentességet

91 GABLER 1985, 22.

92 Ulbert 1971, 113.

93 KÜNZL 1997, 18.

94 Kellner 1980, 179. A többi raetiai műhely Straubing, Günzburg, Aislingen, Schwabmünchen, Regensburg. A kérdéshez ld. EDEL 1981, 103-186; FISCHER 1990, 56.

95 A "raetiai" kerámia pannoniai műhelyei: Poetovio: CURK ET AL. 1984, 81; Savaria: SzőNYI 1973, 99; VARGA 2009, 209-260; Vindobona: GABLER 1978, 124; Aquincum: KuZsinszKy 1932, 273.

96 VARGA 2009, 219.

97 GASSNER 1990, 273. 
élvezett, ${ }^{98}$ nem véletlen, hogy a galliai majd a rajnai áru csakúgy mint a trieri importált kerámia ${ }^{99}$ éppen a ripa Pannonica körzetében jelentős. Jól ismert tény, hogy a Severus dinasztia sokoldalúan , többek közt olyan gazdasági kedvezményekkel támogatta a dunai tartományokat, amelyek konjunkturát teremtettek. ${ }^{100} \mathrm{Nem}$ véletlen, hogy a galliai-germaniai provinciákból származó áruforgalom ekkor volt a legerősebb, ami esetleg a vámtételek enyhítésének is köszönhető.

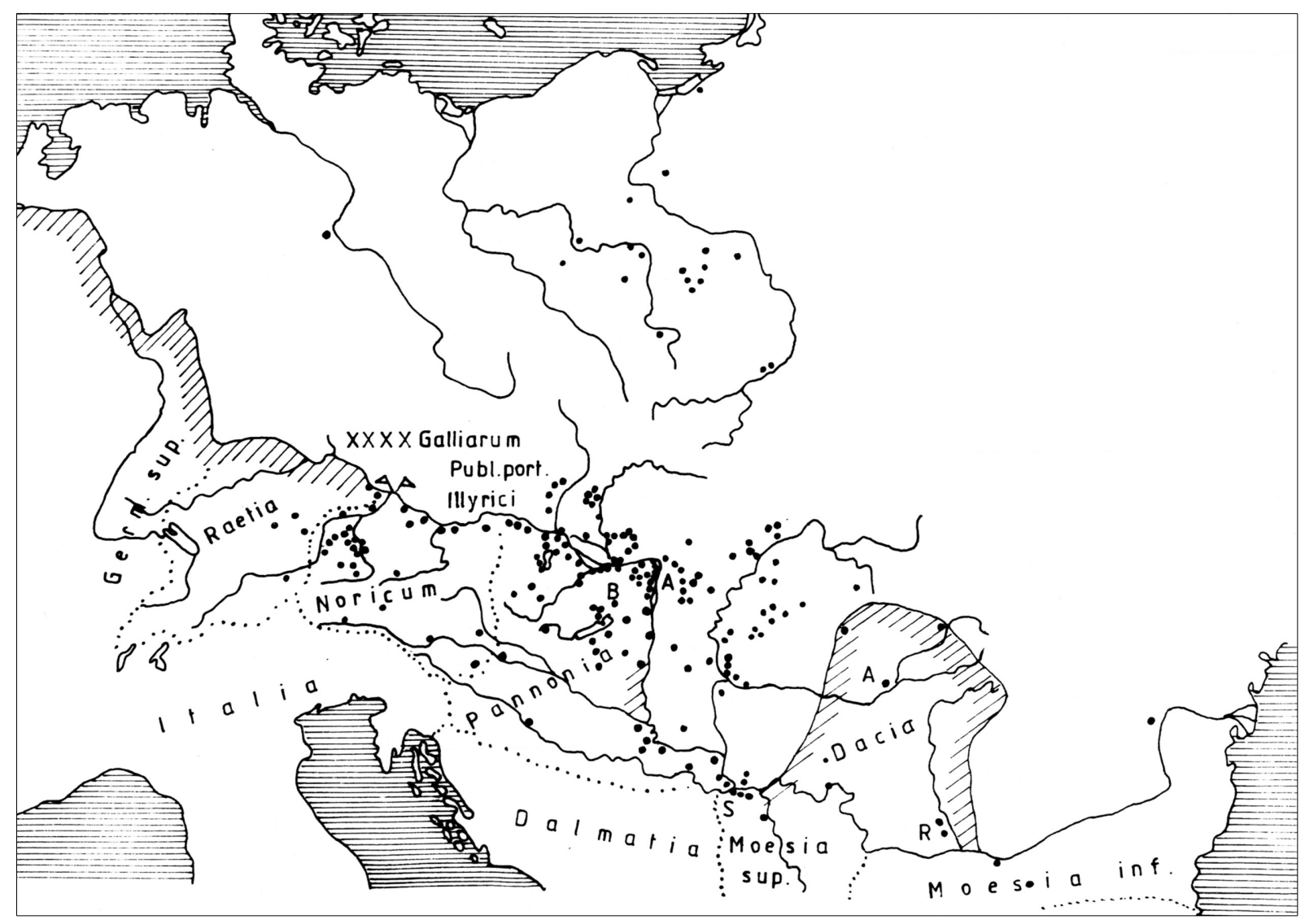

Fig. 3. A westerndorfi sigillaták lelőhelyei.

\section{A vámok kérdése a régészeti források tükrében}

A vámok, ${ }^{101}$ vámkerületek kérdését korábban alig vizsgálták a régészeti források segítségével, az áruforgalom összefüggéseiben, noha a nyugati provinciák esetében ezt az is indokolta volna, hogy az írott források tanúvallomása ${ }^{102}$ éppen ezeknek a provinciáknak esetében gyérebb. A feliratos emlékek általában vámállomásokat igazolnak, esetleg ezek helyére, szervezetére vonatkozó ismereteinket módosítják. Csak áttételesen használhatók azok az adatok is, amelyeket a vindolandai "writing tablets" publikálásával nyertünk. ${ }^{103}$ Más a helyzet a keleti tartományokban, ahol akár a myrai vámfelirat, vagy az Asia provinciára vonatkozó vámelő́rásokat tartalmazó Monumentum Ephesenum ${ }^{104}$ lényeges új felismerésekkel

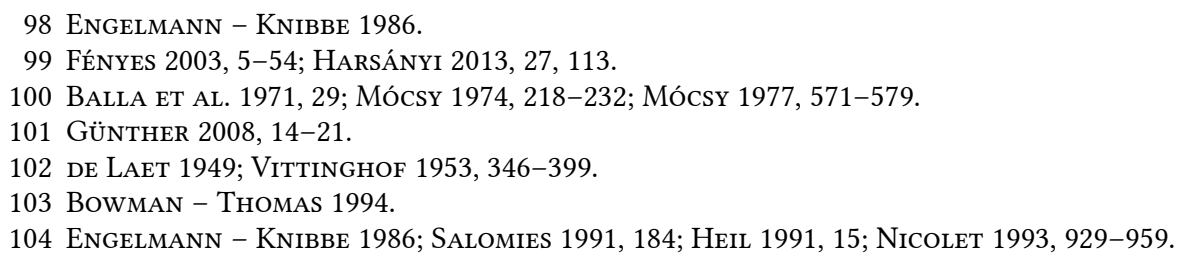


gazdagította a vámszabályokra, a kedvezményekre vagy éppen a vámmentességre, és annak a kereskedelemre gyakorolt hatására vonatkozó ismereteinket. Ezeknek értékelése során a kutatás azt a következtetést vonta le, hogy a római állam a vámokkal elsősorban a birodalom határain kívülről érkező importárut sújtotta; többek közt ezért is tartotta fenn a Ptolemaiosok által bevezetett magas, 25 százalékos vámot. ${ }^{105}$ (Az import áru Plinius (Nat.Hist. VI.101) és Strabon (IV.5.3) egybehangzó adatai szerint valóban drága lehetett.) Ugyanakkor hangsúlyozták, hogy az állam - ha már szervezi a vámigazgatást - azt éppen a "belkereskedelem" előmozdítása, a belső piacok forgalmának élénkítése érdekében szabályozza, ${ }^{106} \mathrm{~s}$ ennek támogatása céljából esetenként még a vámokból származó állami bevételek egy részéről is hajlandó lemondani ${ }^{107}$ vagy azokat más formában ellentételezni. ${ }^{108}$ Drexhage ennek megfelelően a kormányzat flexibilitasát emelte ki, amely vámkedvezményekkel éppen impulzust akart adni a belső áruforgalomnak, amely elől el akarta hárítani a nehézségeket. ${ }^{109} \mathrm{~A}$ vámelőírások éppen ezért aránylag rugalmasan követték a gazdasági élet változásait, a tételek nagyságával, a privilégiumokkal vagy éppen felmentésekkel a piac kihívásaira válaszoltak. Ugyanakkor a vámállomásokon a bürokratikus eljárás, a kezelés módja - a papyrusok adatai szerint - sokkal bonyolultabb; az írásos dokumentumok használata sokkal kiterjedtebb lehetett, mint azt eddig elképzelhettük. ${ }^{110} \mathrm{~A}$ másik tényleges nehézséget a drága szállítási költségek jelenthették, ${ }^{111}$ amelyek elsősorban a szárazföldi, tehát kocsin történő szállítás esetében emelhették lényegesen a kiadásokat.

Ugyanakkor H.-J. Drexhage kétségbevonja, hogy a belső vámoknak lényeges befolyásuk lett volna az áruforgalomra, ha hatásuk egyáltalán felismerhető lenne. ${ }^{112}$ A fentiek: az itáliai sigillaták Augustus-kori elterjedése, a nyugati és a Duna-vidéki provinciák kerámiaspektrumának jelentős különbségei, több árufajtának csupán a vámhatárokig történő elterjedése azonban ennek ellenkezőjét bizonyítják; egyfelől azt, hogy a régészeti források révén a különbségek felismerhetők, másrészt, hogy a vámok az áruforgalomra nem lebecsülendő, esetenként az árumegállításig terjedő hatást gyakorolhattak. Mindezzel nem azt kívánjuk hangsúlyozni, hogy a belső vámok alapjában akadályozták a kereskedelmet, és csak terheket róttak a belső piac szereplőire, sokkal inkább azt, hogy szerepük terelő, az elosztást megkönnyítő lehetett. A 2. században főként a két nagy európai hadsereg: a rajnai és a dunai utánpótlásának zökkenőmentes ellátását, az azonos gyártóhelyről, ipari centrumokból történő rendelések teljesítése során fellépő esetleges zavarok kiküszöbölését szolgálhatták. Drexhage cáfolata a felsorakoztatott érveket figyelmen kívül hagyva, egyedül a westerndorfi áru elterjedését próbálja spekulativ úton más okokkal magyarázni. ${ }^{113}$

Bár érvelése ebben az esetben sem meggyőző, de ha ezt az argumentálást Westerndorf esetében el is fogadnánk, magyarázat nélkül maradnak az itáliai sigillaták, a vékonyfalú kerámia, a raetiai áru, a mécsesek és más importáru spektrumok különbségei, amelyeket nem írhatunk csupán a véletlen számlájára. A kereskedelemnek tehát számolnia kellett a belső vámokkal is.

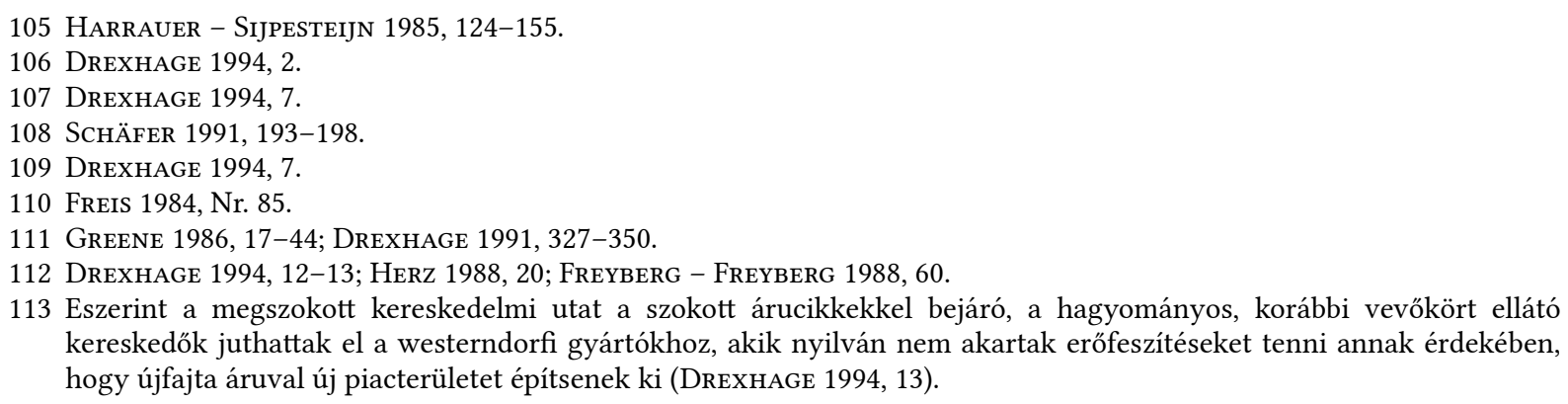
kereskedők juthattak el a westerndorfi gyártókhoz, akik nyilván nem akartak erőfeszítéseket tenni annak érdekében, hogy újfajta áruval új piacterületet építsenek ki (DrEXHAGE 1994, 13). 
A vámrendszer ennek megfelelően nemcsak szabályozta a kereskedelmet, hanem irányát és intenzitását is meghatározta; szándéka az áruforgalom terelésével, a kereskedelemnek a birodalom érdekeinek megfelelő irányba, az utánpótlás érdekében történő előmozdítása. Kivételeket természetesen minden szabályozás tartalmaz; ezeknek körét éppen a Monumentum Ephesenumból ismerhetjük meg. Csupán spekulatív megközelítéssel a birodalmon belüli gazdasági tömbök kérése sem vizsgálható.

A vámkerületek jelentőségét az áruforgalom, a szállítmányok összetétele igazolja. A felsorakoztatott argumentumok köre az észak-afrikai terra sigillata chiara és az ún. Argonnenware piacterületének eltérésével tovább bővíthető; ${ }^{114}$ ennek markáns különbségei ismét a tömbök irányába mutatnak. Schnurbein eredményei és saját korábbi megfigyeléseim után egy újabb összefoglaló munka szerzője ${ }^{115}$ is a vámkerületeket - talán némi túlzással quasi egymástól független gazdasági egységeknek tekinti.

\section{Irodalom}

Alzinger, W. 1955: Kleinfunde von Aguntum aus den Jahren 1950 bis 1955. Wien.

BAATZ, D. 1962:Mogontiacum: Neue Untersuchungen am römischen Legionslager in Mainz. Limesforschungen 4. Berlin.

Schönberger, H. - Simon, H.-G. 1976: Das augusteische Römerlager Rödgen. Die Funde aus den frühkaiserzeitlichen Lager Rödgen, Friedberg, Bad Nauheim. Limesforschungen 15. Berlin.

BAILEY, D. M. 1980: Catalogue of the Lamps in the British Museum. II., London.

Balla, L. - Buocz, T. - Mócsy, A. - SzentléLeky, T. 1971: Die römischen Steindenkmäler von Savaria. Budapest.

BArkóczi, L. 1988: Pannonische Glasfunde in Ungarn. Studia Archaeologica 9. Budapest.

BAuER, I. 1998: Zum Fundmaterial der römischen Kaiserzeit. in: Neugebauer, J.W. (ed.): Vom römischen Lagerdorf zum mittelalterlichen Lesehof. Katalog des Stadtmuseums Klosterneuburg, Klosterneuburg.

Bergamini, M. 1973: La ceramica romana. Quaderni degli Studi Romagnoli. Faenza.

Bezeczky, T. 1985: P. Iturius Sabinus amphorája Vetus Salinában. Folia Archaeologica 36, 69-74;

Bezeczky, T. 1987: Roman Amphorae from the Amber Route in Western Pannonia. British Archaeological Reports. International Series 386. Oxford.

Bezeczky, T. 1995: Roman Amphora Trade in Pannonia. In: Hajnóczi, Gy.(ed.): La Pannonia e l'Impero Romano. Atti del convegno internazionale.Accademia d'Ungheria e l'Istituto Austriaco di Cultura. Milano, 155-175.

Bezeczky, T. 1998: The Laecanius amphora stamps and the villas of Brijuni. Wien.

Bjelajac, L. 1996: Amfore gornjomezijskog Podunavlja (Amphorae of the Danubian basin in Upper Moesia). Posebna izdanja / Arheološki institut, Beograd ; knj. $30=$ Monographies / Archaeological Institute, Belgrade ; no 30. Belgrade.

Bowman, A.K. - ThomA, J. D. 1994: Vindolanda. The Latin Writing-Tablets. London. 
Brecciaroli Taborelli, L. 2000: Vasetti in ceramica invetriata. in: Alle origini di Biella. La necropoli. Torino, 135-142.

BRentcheloff, B. 1976: Index sigillorum Forum Julii Narbonensis. Saint Raphael.

Bruni, B. (ed.) 1995: Ateius e le sue fabbriche. La produzione di sigillata ad Arezzo, a Pisa e nella Gallia meridionale. Annale di Scuola Normale Pisa 25. Pisa, 271-461.

Bruno, B. 2005: Le anfore da trasporto. in: GANdolfi, G. (ed.): La ceramica e i materiali di età romana. Classi, produzione, commerci e consumi. Bordighera, 353-394.

Buocz, T. 1969: Vámbélyegző Savariából. Vasi Szemle 23, 300-304.

Cherubini, L. - Del Rio, A. 1997: Officine ceramiche di età romana nell'Etruria settentrionale costiera.; impianti, produzioni, attrezzature. Acta Rei Cretariae Romanae Fautorum 35, 133-141.

Curk, I. - Gulić, M. - Tusek, I. 1984: Zur Sigillataproduktion von Poetovio. Acta Rei Cretariae Romanae Fautorum 23-24, 61-68.

Curk, I. 1977: Einiges über die padanischen Sigillaten von Emona. Acta Rei Cretariae Romanae Fautorum 17-18, 81-84.

Czysz, W. - Hartmann, H. - Kaiser, H. - Mackensen, M. - Ulbert, G. 1981: Römische Keramik aus Bad Wimpfen - Die Reliefsigillata aus dem Vicus Wimpfen im Tal. Forschungen und Berichte zur Vor- und Frühgeschichte in Baden-Württemberg 11. Stuttgart.

DE LAET, S.J. 1949: Portorium. Étude sur l'organisation douanière chez les Romains surtout à l'époque du Haut-Empire. Brugge.

De LucA, G. 2000: Überlegungen zur Bleiglasurkeramik aus Pergamon. Acta Rei Cretariae Romanae Fautorum 36, 129-146.

Deringer, H. 1965: Römische Lampen aus Lauriacum. Forschungen in Lauriacum, 9. Linz.

Desbat, A. 2000: Les ateliers lyonnais et viennois à l'époque d'Auguste e leur rapport avec les ateliers padans. Documenti di Archeologia 21, 79-92.

Desbat, A. 2001: L'artisanat céramique à Lyon durant l'époque romaine. Acta Rei Cretariae Romanae Fautorum 37, 19-22.

Dimitrova-Milčeva, A. 2000: Terra sigillata und dünnwandige Keramik aus Moesia inferior (Nordbulgarien). Sofia.

Doвó, Á. 1968: Die Verwaltung der römischen Provinz Pannonien von Augustus bis Diocletian. Budapest.

Drexhage, H.-J. 1991: Preise, Mieten, Pachten, Kosten und Löhne im römischen Ägypten bis zum Regierungsantritt Diokletian. St. Katarinen.

Drexhage, H.-J. 1994: Einflüsse des Zollwesens auf den Warenverkehr im römischen Reichhandelshemmend oder handelsfördernd? Münstersche Beiträge zur antiken Handelsgeschichte 13, 1-15.

Edel, T. 1981: Rätische Ware. in: Weber, G. et al. (eds.): Neue Ausgrabungen an 'Apollo Grannus Heiligtum' in Faimingen. Zwischenbericht. Bericht des Römisch-Germanischen Kommission 62, 103-186.

Engelmann, H. - KnibBe, D. 1986: Monumentum Ephesenum: Ein Vorbericht. Epigraphica Anatolica 8, 19-32.

EtTlinger, E. 1983: Novaesium IX. Die italischen Sigillaten von Neuss. Limesforschungen 21. Berlin. 
FAgA, I. 2011: La ceramica a pareti sottili. in: Bergamini, M (ed.) Scoppieto II. I materiali. Firenze, $127-227$.

FÉNYEs, G. 2003: Import kerámiák és helyi utánzataik Brigetioból (kivétel terra sigillata) (Importierte Keramik und ihre lokalen Nachahmungen aus Brigetio (außer Terra Sigillaten). KomáromEsztergom Megyei Múzeumok Közleményei 10, 5-54.

Fingerlin, G. 1970-1971: Dangstetten, ein augusteisches Legionslager am Hochrhein. Vorberichte über den Grabungen 1967-1969. Bericht des Römisch-Germanischen Kommission 51-52, 197-232.

Finocchiaro, A. 1999: Ceramica "tipo Aco" ad Altinum. Quaderni di Archeologia del Veneto 15, 146-159.

Fischer, Th. 1990: Das Umland des römischen Regensburg. Materialhefte der Bayerischen Vorgeschichte 42. München.

Fitz, J. 1993: Die Verwaltung Pannoniens in der Römerzeit. Budapest.

FrANCE, J. 1993: Adminstration et fiscalité douanières sous le rèègne d'Auguste. La date de la création de la quadragesima Galliarum. Melange de l'Écoles française de Rome 105, 895-927.

France, J. 2001: Quadragesima Galliarum. L'organisation douanière des provinces alpestres, gauloises et germaniques de l'Empire romain (Ier siècle av.7.-C. - III e siècle apr. f.-C.) Collection de l'École Française de Rome 278. Rome.

FREIS, H. 1984: Historische Inschriften zur römischen Kaiserzeit von Augustus bis Konstantin. Darmstadt.

von Freyberg, H.-U. 1988: Kapitalverkehr und Handel im Römischen Kaiserreich (26 v. Chr. - 232 n.Chr.). Freiburg.

Gabler, D. - Kelemen, M. 1984: Olio betico in Pannonia. Amfore ispaniche nella Valle danubiana. Archivo Español de Arqueologia 57, 121-138.

GABLER, D. 1976: Importált reliefdíszű terra sigillaták és pannoniai utánzataik. Archaeologiai Értesítő 103, 34-51.

GABler, D. 1978: Die Keramik von Vindobona in: Vindobona. Die Römer im Wiener Raum. Ausstellungskatalog des Historischen Museums der Stadt Wien. Wien.

Gabler, D. 1981: Zum Anfangsdatum des römischen Carnuntum. Mitteilungen der Gesellschaft der Freunde Carnuntums, 2-32.

GABLER, D. 1982: Die südgallischen Sigillaten in Pannonien. Einige Besonderheiten ihrer Verbreitung. Acta Rei Cretariae Romanae Fautorum 21-22, 52-53.

GABLER, D. 1985: Die Unterschiede im Keramiimport der Rhein und Donauprovinzen. Münstersche Beiträge zur Antiken Handelsgeschichte 4.1, 3-29.

GABLER, D. 1986: Differences between imported pottery in the western and Danubian Provinces of the Roman Empire. Acta Archaeologica Academiae Scientiarum Hungaricae 38, 93-104.

GABlER, D. 1990: Terra sigillata az inotai és a pannoniai halomsírokban. In: PALÁGYi, S. (ed.) Noricumi-pannoniai halomsírok. Veszprém 149-162;

GABLER, D. 1991: Italische Sigillaten aus den canabae legionis in Carnuntum. Carnuntum fahrbuch, $229-252$.

Gabler, D. 2000: Mittelitalische Terra sigillata in Pannonien? Carnuntum fahrbuch, 9-25.

GABLER, D. 2001: A balácai terra sigillaták 3. Balácai közlemények 6, 117. 
Gassner, V. 1989: Amphoren aus Carnuntum. Überlegungen zu ihrem wirtschaftsgeschichtlichen Aussagewert. Münsterische Beiträge zur antiken Handelsgeschichte 8, 52-72.

GAssNer, V. 1990: Feinware aus Carnuntum. Funde von den Grabungen auf den „Mühläckern” 19781988. Carnuntum fahrbuch, 253-292.

Gervasini, C. 2005: La ceramica a pareti sottili. In: GANDOLFI, D. (ed.): La ceramica e i materiali di età romana. Classi, produzioni ,commerci e consumi. Bordighera, 279-310.

Giroussens, G. 1998: Les estampilles sur céramiques sigillées de l'anse Saint-Gervais a Fos-sur-Mer. S.F.C.A.G. Actes du congrés d'Orange.12-15 mai 1998. Marseille.

Greene, K. 1986: The Archaeology of the Roman Economy. London.

Groн, S.: 1996 Die Insula XLI von Flavia Solva. Ergebnisse der Grabungen 1959 und 1989 bis 1992. Sonderschriften des Österreichischen Archäologischen Instituts 28. Wien.

GuÉRY, R. 1987: Nouvelle approche sur la diffusion de la terra sigillata tardo-italique. Acta Rei Cretariae Romanae Fautorum 25-26, 131-136.

GüNTHER, S. 2008: Vectigalia nervos esse rei publicae. Die indirekte Steuern in der römischen Kaiserzeit von Augustus bis Diocletian. Philippika. Marburger Altertumskunde Abhandlungen 26. Wienbaden.

Harrauer, H. - Sijpesteijn, P.J. 1985: Ein Dokument zu Roms Indien P Vindob G 40822 . Anzeiger der Österreichischen Akademie der Wissenschaften. Philosophisch-historische Klasse 122,124-155.

Harsányi, E. 2013: Die Trierer schwarz engobierte Ware und ihre Imitationen in Noricum und Pannonien. Austria Antiqua 4. Wien.

HÁRshegyi, P. 2010: Amphorae from Early Roman Contexts. The case of Viziváros (Budapest, Hungary). Acta Rei Cretariae Romanae Fautorum 41, 51-54.

HeIL, M. 1991: Einige Bemerkungen zum Zollgesetz aus Ephesos. Epigraphica Anatolica 17, 9-18.

Herz, P. 1988: Studienzur römischen Wirtschaftsgesetzgebung. Stuttgart.

Hochuli-Gysel, A. 1977: Kleinasiatische glasierte Reliefkeramik (50 v. Chr. bis 50 n. Chr.)und ihre oberitalischen Nachahmungen. Acta Bernensia 7. Bern.

Hochuli-Gysel, A. 1976: Bleiglasierte Keramik aus Tarsos in Cypern. Report of the Department of Antiquities Cyprus, 226-241.

Istenić, J. - PlesničAr-Gec, L. 2001: A pottery kiln at Emona. Acta Rei Cretariae Romanae Fautorum $37,141-146$.

Jacobsen, G. 1995: Primitiver Austausch oder freier Markt? Untersuchungen zum Handel in den gallisch-germanischen Provinzen während der römischen Kaiserzeit. PHAROS 5. St. Katarinen.

Kelemen, M. 1987: Roman Amphorae in Pannonia. North Italian Amphorae. Acta Archaeologica Academiae Scientiarum Hungaricae 39, 3-45.

Kelemen, M. 1988: Roman Amphorae in Pannonia II. Acta Archaeologica Academiae Scientiarum Hungaricae 40, 117-123.

Kelemen, M. 1990: Roman Amphorae in Pannonia III. Acta Archaeologica Academiae Scientiarum Hungaricae 42, 147-193.

Kellner, H.-J. 1980: Beobachtungen in Westerndorf - St.Peter 1976. Fahrbuch der Bayerischen Bodendenkmalpflege 21, 175-181.

Kenrick, P. M. 1997: Cn. Ateius - the inside story. Acta Rei Cretariae Romanae Fautorum 35, 185-188. 
Klumbach, H. 1966: Eine oberitalische Relieftasse aus Giubiasco. In: Degen, R. - Drack, W. - Wyss, R. (eds.): Festschrift Emil Vogt : Beiträge zur Prähistorie und Archäologie der Schweiz. Zürich, 173-182.

KolNıK, T. 1980: Römerzeitliche Gräberfelder in der Slowakei. Bratislava.

KrAft, K. 1962: Zum Legionslager Augsburg-Oberhausen. in: Werner, J. (ed.): Aus Bayerns Frühzeit. F. Wagner zum 75. Geburtstag. Schriftenreihe zur Bayerischen Landesgeschichte 62, 139-156.

KreKović, E. 1981: Römische Importkeramik in der Slowakei. Slovenská Archeológia 29, 374.

Kuzsinszky, B. 1932: A gázgyári római fazekastelep. Budapest Régiségei 11. Budapest.

KüNZL, S. 1997: Die Trierer Spruchbecherkeramik. Dekorierte Schwarzfirniskeramik des 3. und 4. fahrhunderts n.Chr. Trierer Zeitschrift für Geschichte und Kunst des Trierer Landes und seiner Nachbargebiete. Beiheft 21. Trier.

LA BAume, P. 1958: Frührömische Töpferöfen aus der Lungengasse. Kölner fahrbuch für Vor- und Frühgeschichte 3, 26-54.

LAdSTÄTteR, S. 2000: Die materielle Kultur der Spätantike in den Ostalpen. Eine Fallstudie am Beispiel der westlichen Doppelkirchenanlage auf dem Hemmaberg. Mitteilungen der Prähistorischen Kommission 35. Wien.

LAVIzZARi-Pedrazzini, M. P. 1987: Ceramica romana di tradizione ellenistica in Italia settentrionale. Il vasellame di "tipo Aco". Pubblicazioni della Facoltà di Lettere e Filosofia dell'Università di Pavia 42, 43-47.

LAVIzZARi-Pedrazzini, M. P. 2000: Echi ellenistici e microasiatici nella ceramica italosettentrionale. Acta Rei Cretariae Romanae Fautorum 36, 365-369.

Leblanc, O. 2001: Production de céramiques à Saint Roman-en-Gal (Rhône, France). Bilan de 25 années de recherche sur le site. Acta Rei Cretariae Romanae Fautorum 37, 45-55.

Leibundgut, A. 1977: Zu den römischen Fundlampen der Schweiz. Arheološki Vestnik 25, 100-110.

Leibundgut, A. 1977: Die römischen Lampen in der Schweiz. Bern.

Maccabruni, C. 1981: Ceramica invetriata nella necropoli romana del Canton Ticino. Reperti romani da scavi nelle attuali terre del Canton Ticino. Lugano.

Maccabruni, C. 1985: Tipologia della ceramica invetriata di età romana nell'area del Ticino. Considerazioni preliminari. in: La ceramica invetriata tardoromana e alto medievale. Atti del Convegno - Como, 14. marzo 1981. Archeologia dell' Italia settentrionale 2. Como, 16-30.

Maccabruni, C. 1994: Ceramica invetriata con decorazione a rilievo. Nuovi ritrovamenti del territorio pavese. Alba Regia 24, 49-61.

Maioli, M. G. 1972-1973: Vasi a pareti sottili grigie dal Ravennate. Acta Rei Cretariae Romanae Fautorum 14-15, 106-124.

MakJANić, R. 1981: “Reljefne šalice tipa 'Sarius' iz Osora”. „(Sarius" cups with relief decoration from Ošor.) Vjesnik Arheološkog muzeja u Zagrebu. Ser. 3. 14, 50-55.

Makjanić, R. 1995: Terra sigillata. In: Makjanić, R. - Koščević, R. (eds.): Siscia. Pannonia Superior. British Archaeological Reports International Series 621. Oxford.

Marabini Moevs, T. 1973: Roman thin walled pottery from Cosa 1948-1954. Memoire of the American Academy Rome 32 (1973) 211-244.

MASELli Scotti, F. 1984: La ceramica ad Aquileia.II. Il vasellame da mensa. Antichità altoadriatiche 24, $39-70$. 
Menchelli, S. 1994: Da Cn. Ateius ai vasai tardo italici; alcuni considerazioni sulla terra sigillata "pisana". Bolletino Storico Pisano 63, 9-34.

Menchelli, S. 1995: Ateius e gli altri, produzioni ceramiche in Pisa e nell'ager pisanus fra tarda reppublica e primo impero. Annali di Scuola Normale, Pisa 25, 333-350

Mócsy, A. 1962: s. v. Pannonia. In: Pauly-Wissowa Realencyklopädie der klassischen Altertumswissenschaft supplementum IX. Stuttgart, 515-770.

Mócsy, A. 1974: Pannonia and Upper Moesia. A History of the Middle Danube Provinces of the Roman Empire. London - Boston.

Mócsy, A. 1977: Pannonien und die Soldatenkaiser. In: Aufstieg und Niedergang der Römischen Welt II. 6, $557-582$.

Nagy, A. 2014: New amphora finds from Savaria. A preliminary report. Acta Rei Cretariae Romanae Fautorum 43, 129-131.

Neumann, A. 1967: Forschungen in Vindobona 1948 bis 1967. 1.Teil: Lager und Lagerterritorium. Der römische Limes in Österreich 23. Wien.

Neumann, A. 1967: Lampen und andere Beleuchtungsgeräte aus Vindobona. Der römische Limes in Österreich 22. Wien.

Nicolet, C. 1993: Le Monumentum Ephesenum et la délimitation du Portorium d' Asie. Melange de l'Écoles française de Rome 105, 929-959.

Oldenstein, J.(ed.) 1982: Der obergermanisch-rätische Limes des Römerreiches. Fundindex. Frankfurt am Main.

ǾRSTED, F. 1985: Roman Imperial Economy and Romanisation. A Study in imperial Administratiom and the public Lease System in the Danubian Provinces from the first to the third century $A D$. Kopenhagen.

ǾRSTED, P. 1989: Ad Publicanos. Zwei Zollstationen und ihre Bedeutung für die Territorialgeschichte von Vienne bzw. Emona. Acta Archaeologica Academiae Scientiarum Hungaricae 41, 175-188.

Oxe, A. - Comfort, H- Kenrick, P. 2000: Corpus Vasorum Arretinorum, second edition. A Catalogue of the Signatures, Shapes and Chronology of Italian Sigillata. Antiquitas 3. Bonn.

Petrikovits, H. von 1970: Der Wandel römischer Gefäßkeramik in der Rheinzone. In: Droege, G. SCHÖLLER, P. - SCHÜTZEICHel, R. - ZENDER, M. (eds): Landschaft und Geschichte. Festschrift für Franz Petri zu seinem 65. Geburtstag am 22. Februar 1968. Bonn, 496-518.

Petrikovits, H. von 1983: Die römischen Provinzen am Rhein und an der oberen und mittleren Donau im 5. Fahrhundert n. Chr. Ein Vergleich. Sitzungsberichte der Heidelberger Akademie der Wissenschaften, Philosophisch-historische Klasse. Heidelberg.

Pflaum, H.-G. 1974: Abrégé des procurateurs equestres. Paris.

PlesničAR-GeC, L. 1987: Thin walled pottery from Slovenia. Acta Rei Cretariae Romanae Fautorum 25-26, 451-464.

Premk, A. 1987: Production of early Roman Pottery in Sirmium. Acta Rei Cretariae Romanae Fautorum 25-26, 437-450.

Pucci, G. 1975: Una matrice per terra sigillata tardo-italica da Pisa. Antichità Pisane 4, 1-4.

RICCI, A. 1985: Ceramica a pareti sottili. In: Atlante delle forme ceramiche II. Ceramica fine romana nel bacino mediterraneo. Supplemento all' Enciclopedia dell'Arte Antica. Roma, 231-357. 
Righini, V. 1979: Ceramica "tipo Aco" e tipos Sarius marcata a Faenza. Bollettino del Museo Internazionale delle Ceramiche di Faenza 65, 213-240.

RuprechtsBerger, E. M. 1983: Zum römerzeitlichen Gräberfeld von Lentia-Linz. Zum römerzeitlichen Gräberfeld von Lentia-Linz .Linzer archäologische Forschungen. Sonderheft 5. Linz.

SAlomies, O. 1991: Zu einigen Stellen im Zollgesetz der Provinz Asia. Zeitschrift für Papyrologie und Epigraphik 86, 184-186.

SANIE, S. 1981: Civilizaţia romană éa est de Carpaţi şi romanitatea pe teritoriul Moldavei (sec. II î.e.n. III e.n.). Iaşi.

Saranović-Svetek, V. 1971: Terres sigillées de la collection archéologique du Musée de Vinkovci. Starinar 22, 167-176.

ŠAšEL, J. 1966: Keltisches portorium in den Ostalpen. In: SwobodA-Milenovic, R. M. (ed.): Corolla memoriae Erich Swoboda dedicata. Graz, 198-204.

SCHÄFER, Ch. 1991: Zur $\Sigma$ OPAГ IS von Sklaven in der lex portorii provinciae Asiae. Zeitschrift für Papyrologie und Epigraphik 86, 193-198.

Schindler, M. - Scheffenegger, S. 1977: Die glatte rote Terra sigillata vom Magdalensberg. Archäologische Forschungen $z u$ den Grabungen auf dem Magdalensberg 5. Kärntner Museumsschriften 62. Klagenfurt.

SCHINDLER-KAudelKA, E. 1975: Die dünnwandige Gebrauchskeramik vom Magdalensberg. Kärntner Museumsschriften 58. Klagenfurt.

SchindLer-KAUDELKA, E. 1980: Die römische Modelkeramik vom Magdalensberg. Kärntner Museumsschriften 66. Klagenfurt 1980.

Schindler-Kaudelka, E. 1998: Die dünnwandige Gebrauchskeramik vom Magdalensberg 2. Die pareti sottili vom Südhang des Magdalensberges. In: Piccottini, G. (ed.): Die Ausgrabungen auf dem Magdalensberg 1980 bis 1986. Magdalensberg-Grabungsbericht 16. Klagenfurt, 389-427.

Schnurbein, S. von 1974: Bemerkenswerte Funde aus einer Töpferei des Hauptlagers von Haltern. Germania 52, 77-88.

Schnurbein, S. von 1977: Römische Gräberfeld von Regensburg. Archäologische Forschungen in Regina Castra - Reganesburg. Materialhefte zur bayerischen Vorgeschichte A 31. Kallmünz/Opf.

Schnurbein, S. von 1977: Die Produktion der Haltener Töpfereien. Acta Rei Cretariae Romanae Fautorum 17-18, 38-50.

Schnurbein, S. von 1982: Die kulturgeschichtliche Stellung des nördlichen Rätien - ein Beitrag zur Deutung archäologischer Fundgruppen. Bericht des Römisch-Germanisches Kommission 63, 5-16.

Schnurbein, S. von 1982: Die unverzierte Terra sigillata aus Haltern - mit einem Beitrag von $\mathcal{f}$. Lasfargues und M. Picon. Bodenaltertümer Westfalens 19/1-2. Münster.

Sena ChiesA, G. 1979: Scavi dell'Università degli Studi di Milano nella necropoli romana di Angera (campagna di scavo 1975-1978). Osservazioni pleriminari. Acme 32, 37-79.

StArac, A. 1997: Napomene o amforama Dressel 6 B. In: ČEČUK, B. (ed.): Arheoloske istrazivanja u Istrii. Zagreb, 143-161.

Stenico, A. 1964: Localizzata a Cremona di una produzione di vasellame "tipo Aco". Acta Rei Cretariae Romanae Fautorum 5-6, 51-59. 
Szabó, M. - Guillaumet, J.P. - Cserményi, V. 1994: Fouilles franco hongroise a Velem-Szentvid. Recherches sur la fortification latèniene. Acta Archaeologica Academiae Scientiarum Hungaricae 46, 107-126.

SzőNYI, E. 1973: Die sogenannte rätische Keramik in Pannonien. Acta Archaeologica Academiae Scientiarum Hungaricae 25, 87-108.

Tassaux, F. 1982: Laecanii. Recherches sur une famille sénatoriale d'Istrie. Melange de l'Écoles française de Rome 94, 227-269.

UlBeRT, G. 1959: Die römischen Donau-Kastelle Aislingen und Burghöfe. Limesforschungen 1. Berlin.

UlBeRT, G. 1965: Der Lorenzberg bei Epfach. Die frührömische Militärstation (Epfach III). Münchner Beiträge zur Vor- und Frühgeschichte 9. München.

UlberT, G. 1971: Zur Grenze zwischen den römischen Provinzen Norikum und Raetien am Inn. Bayerische Vorgeschichtsblätter 36, 101-123.

VÁGÓ, E. B. 1977: Die oberitalisch-padanische Auflagen-Sigillata in Transdanubien. Acta Archaeologica Academiae Scientiarum Hungaricae 29, 77-124.

Varga, N. 2009: Raetiai típusú kerámia Savariában. Communicationes Archaeologicae Hungariae, 209-260.

Vegas, M. 1969-1970 : Aco-Becher. Acta Rei Cretariae Romanae Fautorum 11-12, 107-117.

Vertet, H. - Lasfargues, A - Lasfargues, S. 1968: Observations sur les gobelets d'Aco de l'atelier de la Muette (Lyon). Revue Archéologique de Centre 7, 35-44.

Vittinghoff, F. 1953: s. v. Portorium. In: Pauly-Wissowa Realencyklopädie der klassischen Altertumswissenschaft 22. Stuttgart, 346-399.

Zabehlicky-Scheffenegger, S. 1982: Die Geschäfte des Herrn Lucius G. Ein Arbeitsbericht. Acta Rei Cretariae Romanae Fautorum 21-22, 105-115.

Zabehlicky-Scheffenegger, S. 1991: Frühe padanische Filialen einiger arretinischen Töpfereien. Acta Rei Cretariae Romanae Fautorum 29-30, 95-104.

Zabehlicky-Scheffenegger, S. 1995: Der Italiener in Ephesos. Alba Regia 25, 253-271.

ZABehlicky-Scheffenegger, S. 1998 Neues zur italischen glatten Sigillata vom Magdalensberg. 1960 bis 1986. Klagenfurt. 